\title{
Organization, usefulness and limitations of an ATBI (All Taxa Biodiversity Inventory): the inventory of terrestrial invertebrates in the Mercantour National Park
}

\author{
Louis DEHARVENG \\ Anne BEDOS \\ Christophe DAUGERON \\ Claire VILLEMANT \\ Institut de Systématique, Évolution, Biodiversité, \\ UMR 7205 CNRS, MNHN, UPMC, EPHE, \\ Muséum national d'Histoire naturelle, Sorbonne Universités, \\ case postale 50, 57 rue Cuvier, 75005 Paris (France) \\ deharven@mnhn.fr \\ bedosanne@yahoo.fr \\ daugeron@mnhn.fr \\ villeman@mnhn.fr \\ Mark L. I. JUDSON \\ Institut de Systématique, Évolution, Biodiversité, \\ UMR 7205 CNRS, MNHN, UPMC, EPHE, \\ Muséum national d'Histoire naturelle, Sorbonne Universités, \\ case postale 53, 57 rue Cuvier, 75005 Paris (France) \\ judson@mnhn.fr
}

Deharveng L., Bedos A., Daugeron C., Villemant C. \& Judson M. L. I. 2015. - Organization, usefulness and limitations of an ATBI (All Taxa Biodiversity Inventory): the inventory of terrestrial invertebrates in the Mercantour National Park, in Daugeron C., Deharveng L., Isaia M., Villemant C. \& Judson M. (eds), Mercantour/Alpi Marittime All Taxa Biodiversity Inventory. Zoosystema 37 (1): 9-30. http://dx.doi.org/10.5252/z2015n1a1

\begin{abstract}
We present here the objectives, organization and preliminary results of the invertebrate inventory of the Mercantour National Park ("Terrestrial Invertebrates Module" of the ATBI Mercantour/Alpi Marittime), carried out by 68 scientists and field-collectors from 2009 to 2012. The conceptual framework of an ATBI and the interactions between inventorying and frequently associated research aims are discussed. The sampling strategy adopted combined standardized multi-taxon sampling (continuous and occasional) with individual taxon-centred sampling. The successive tasks of field sampling, specimen coding, sorting and identification, molecular analysis and data management are briefly described. A coherent system of sample coding ensured the traceability of specimens. The project results in terms of sampling effort, abundance of collected invertebrate fauna and biological diversity are presented globally, by techniques, by sites and by higher taxonomic groups: 259,412 specimens were obtained from 761 sorted samples (out of 1243 samples collected), belonging to 1725 identified species and subspecies, in addition to which 37 species new to science have been recognized. These data are progressively being integrated into the CardObs database of the INPN and are partly accessible through the EDIT and
\end{abstract}


KEY WORDS

Biodiversity,

field-sampling,

labelling,

sampling strategy, sampling techniques, southern Alps, specimen traceability.

MOTS CLÉS

Biodiversité, échantillonnage de terrain, étiquetage,

stratégie d'échantillonnage, techniques d'échantillonnage,

Alpes du sud,

traçabilité de spécimens.
GBIF websites. Molecular analyses (barcoding) have provided 2800 sequences (mostly for the COI gene in Gastropoda, Collembola and Hymenoptera). Analysis of these sequences indicates a significant amount of cryptic diversity in the material. From a macro-ecological perspective, endemicity in the park decreases globally from south to north and species richness decreases at higher elevations, but the data are uneven and patterns vary according to group. Based on this four-year experience, it appears that a smaller survey area with lower habitat diversity would be better suited to the aims of an ATBI when the available resources are limited, and would enhance the efficiency of collective work in the field.

\section{RÉSUMÉ}

Organisation, intérêt et limites d'un ATBI (All Taxa Biodiversity Inventory): l'inventaire des invertébrés terrestres dans le Parc national du Mercantour.

Nous présentons les objectifs, l'organisation et les résultats préliminaires de l'inventaire des invertébrés du Parc National du Mercantour ("Module Invertébrés Terrestres », ATBI Mercantour/Alpi Marittime), effectué par 68 scientifiques et collecteurs de terrain de 2009 à 2012. Le cadre conceptuel d'un ATBI, et les interactions entre un inventaire et les approches scientifiques qui lui sont souvent associées sont discutés. La stratégie d'échantillonnage adoptée associe des collectes standardisées multi-taxon (en continu et ponctuelles) avec des collectes individuelles taxon-centrées. Les tâches successives - échantillonnage, codage des spécimens, tri et identifications, analyses moléculaires, gestion des données - sont brièvement décrites. Le codage assure la traçabilité des spécimens. Les résultats du projet (échantillonnage, abondance des invertébrés collectés, diversité biologique) sont présentés globalement, par techniques, par sites et par groupes taxonomiques: 259412 spécimens ont été obtenus dans les 761 échantillons analysés (sur les 1243 collectés) appartenant à 1725 espèces et sous-espèces identifiées, auxquelles s'ajoutent 37 espèces nouvelles pour la science. Ces données sont en cours d'intégration dans la base CardObs (INPN, France) et en partie accessibles (sites web, EDIT et GBIF). Les analyses moléculaires (barcode) ont fourni 2800 séquences (Gastéropodes, Collemboles, Hyménoptères, essentiellement COI): leur analyse suggère une diversité cryptique importante au sein du matériel étudié. Du point de vue macroécologique, l'endémicité dans le parc décroit globalement du sud au nord, et la richesse spécifique des basses aux hautes altitudes, mais les données sont hétérogènes et les patrons varient selon les groupes. Sur la base de cette expérience de quatre ans, il apparait qu'une zone d'étude plus réduite que l'ensemble du PNM avec une moindre diversité d'habitats serait mieux adaptée aux objectifs d'un ATBI compte tenu des ressources disponibles, et améliorerait l'efficacité du travail collectif sur le terrain.

\section{INTRODUCTION}

The aims of biological inventories are to determine the level and patterns of biodiversity in a given area, i.e. the number of taxa, their distribution, the diversity of their biological traits and the diversity of their assemblages. Such inventories have experienced a recent renewal (Mauz 2011) and are currently being conducted around the world by academic scientists, NGOs and amateurs, at various taxonomic, geographic and temporal scales. However, massive inventories, involving a wide range of taxa, remain exceptional (Baldi 1999). They range from large expeditions that mobilize numerous specialists over several months, such as the Santo 2006 expedition (Bouchet et al. 2007), to long-term studies encompassing a large diversity of taxa in a well delimited region, such as the ALAS project in Costa-Rica, which started in 1991 and is still running (http://viceroy.eeb.uconn.edu/alas/ALAS. html). In Europe, possibly the most successful inventories of this type are those of the Bükk National Park in Hungary and the Massane forest in the Pyrénées-Orientales (France). For the Bükk National Park, 9436 animal species are listed, based on a massive inventory conducted from 1981 to 1985
(Vasarhelyi 2007). In the Massane forest, a natural reserve of 336 ha created in 1973, 6556 species have been recorded so far, accompanied by abundant data on their ecology and biology (Garrigue 2014).

The Mercantour/Alpi Marittime inventory project ("MAM" project) in the southwestern Alps was designed in a similar way, but at a much larger geographical scale, since the territory concerned is, for example, 700 times larger than the Massane forest. Coordinated by the Museum für Naturkunde of Berlin and the State Museum of Natural History of Stuttgart, as a workpackage of the European project EDIT (http:// www.atbi.eu/mercantour-marittime), it was the first "All Taxa Biodiversity Inventory” (ATBI) - a term coined by Janzen \& Hallwachs (1994) - of this programme to be implemented in Europe, inspired in part by the large scale inventory of the Great Smoky Mountains (Sharkey 2001; Nichols \& Langdon 2007; Bernard \& Felderhof 2007). The aim of the project was to inventory as completely as possible the biodiversity of the Mercantour and Alpi Marittime parks, initially at just a few reference spots, but later over throughout of the parks (Mauz \& Granjou 2013). Two smaller-scale ATBIs were also established within EDIT, in Slovakia and Germany. EDIT 
ended in February 2011, but further funding was obtained by the parks through a European trans-border programme, ALCOTRA.

The Mercantour and Alpi Marittime parks together extend between latitudes $43.90^{\circ}$ to $44.40^{\circ} \mathrm{N}$, and longitudes $6.60^{\circ}$ to $7.52^{\circ} \mathrm{E}$, covering almost 100000 ha, i.e. a large part of one of the richest hotspots of biodiversity in Europe, the southwestern Alps. With several peaks above $3000 \mathrm{~m}$ (Monte Argentera, at $3297 \mathrm{~m}$, and Cime du Gelas, at $3143 \mathrm{~m}$, being the highest), an altitudinal range of more than 2500 metres, a contrasted climate mixing Mediterranean and Alpine influences, and geological terrains ranging from limestone to crystalline, the habitats of the southwestern Alps are extremely diverse. Because this region was located at the southern limit of the glaciers during the last glaciation, it has retained a large number of endemic plants (Medail \& Quezel 1997; Pawlowski 1970) and invertebrates (Sainte-Claire Deville 1928; Deharveng et al. 2000). Beside the interest of targeting such a remarkable hotspot of biodiversity, the M-AM project represents a departure from traditional biodiversity inventories in its large scale, in terms of taxonomic scope, size of studied area and number of contributing taxonomists. Terrestrial invertebrates are of particular interest in this context, being by far the most diversified group of organisms (Chapman 2009) and the richest in terms of endemics. The Terrestrial Invertebrate Module ("TIM") of the project ran for four years (2009-2012), with fieldwork conducted from 2009 to 2011 in the Mercantour National Park (MNP) area.

This paper provides an overview of the operational organization of the inventory of the terrestrial invertebrates (excluding cavernicolous species) conducted by the TIM in the Mercantour National Park and summarizes the scientific results obtained so far.

\section{OBJECTIVES (FIG. 1)}

The aims of an ATBI are to develop an inventory, as comprehensive as possible, of the plants and animals living in a given territory, including data on the environment and location of collection sites, and the dates of sampling. The completeness of an inventory depends directly on the diversity of the chosen habitats and the methods used to sample them. In practice, however, because ecological and genetic objectives are usually added to such inventories, replicates are needed, resulting in a lower diversity of sampled habitats and hence a lower number of species obtained for a given sampling effort. However, integrating such peripheral objectives, which are not those of an ATBI, does allow investigation of the origin and environmental connections of the observed diversity patterns (Deharveng \& Isaia 2013).

The aims of the TIM were to:

1) carry out a basic inventory of the terrestrial invertebrate fauna;

2) detect and describe taxa new to science;

3) initiate a barcode library for invertebrates of certain target groups;

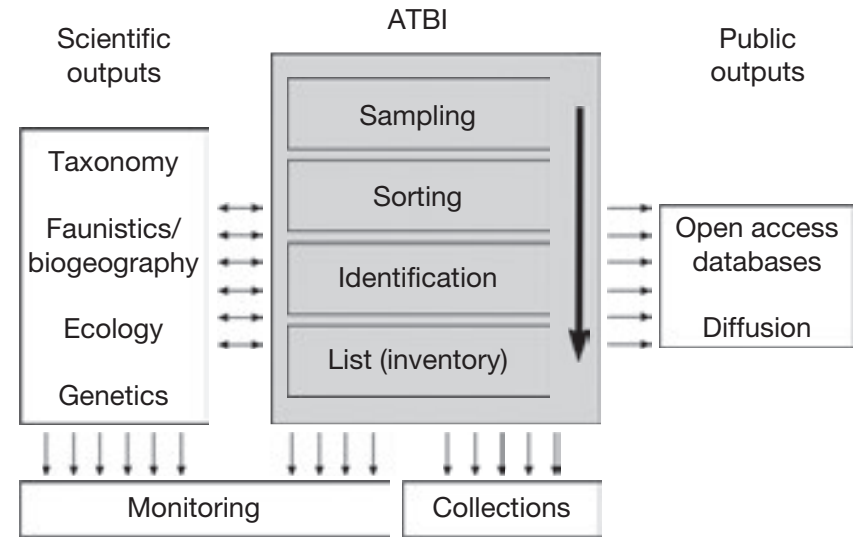

FIG.1. - Main goals and context of an ATBI (after Deharveng \& Isaia 2013).

4) explore cryptic biodiversity in target groups through barcoding;

5) reconstruct patterns of biodiversity and endemism across the study area;

6) document biodiversity changes along altitudinal and latitudinal gradients;

7) develop projects on the cryophilous fauna and on pollinisation (not considered here);

8) provide validated datasets to the Inventaire National du Patrimoine Naturel (France) database for public release;

9) enrich the collections of the Muséum national d'Histoire naturelle (Paris, France).

The ATBI projects of EDIT were initially designed to provide a basis for biodiversity monitoring activities over time (hence the "M" in ATBI+M) from a baseline inventory, but this objective has yet to be implemented.

\section{MATERIAL AND METHODS}

\section{ACRONYMS AND DEFINITIONS}

ATBI All Taxa Biodiversity Inventory;

ATBI+M All Taxa Biodiversity Inventory + Monitoring, official acronyme of the M-AM ATBI, workpackage of EDIT;

CardObs an INPN database in which the Mercantour distribution data are stored;

EDIT European Distributed Institute of Taxonomy;

INPN Inventaire national du Patrimoine naturel (French National Inventory of Natural Heritage);

M-AM Mercantour-Alpi Marittime;

MNHN Muséum national d'Histoire naturelle, Paris;

MNP Mercantour National Park;

SSM Service de systématique moléculaire of the MNHN;

TIM Terrestrial Invertebrate Module;

Sample a collecting event defined by its date, its sampling technique(s), its location and its collectors;

Record presence of a given taxon in a single sample.

WORK ORGANIZATION (FIG. 2)

The ATBI participants contributed either individually or through modules to the inventory. Each module dealt with a particular component of biodiversity: terrestrial (non-subterranean) invertebrates, aquatic (non-subterranean) invertebrates, 
subterranean terrestrial fauna, subterranean aquatic fauna, wild bees, fungi, lichens, bryophytes and vascular plants. The TIM, which was the largest module of the project, focused on non-subterranean terrestrial invertebrates.

\section{Participants and contributors}

The TIM was launched and coordinated by taxonomists of the MNHN. Our first task was to set up a network of specialists for field collections and for identifications, with a large taxonomic coverage and minimal overlap in expertise. A total of 68 researchers, students and PNM staff from 13 different countries were associated with the project $(\mathrm{Ta}-$ ble 1). Of these, 25 participated in field collecting and 62 undertook identifications during the 4 years of the TIM (2009-2012). As reflected in this special issue of Zoosystema, scientific work on the material continues and will do so for many years to come, with additional taxonomists and ecologists becoming involved. As can be seen from Table 6, several major groups still have very few species identified, or even none at all. Because specialists are not currently available for a number of groups, it is clear that a large proportion of the biodiversity will remain undocumented for some time to come.

\section{Workflow summary}

Given the aims of the inventory, the massive collecting techniques used, and the large number of specialists involved, we had to organize the workflow from field trips to deposition in collections in a fairly tightly constrained manner, comparable to the MarBOL workflow in MNHN described by Puillandre et al. (2012). The main tasks performed are briefly summarized below (the different aspects are described in more detail in the relevant sections).

Sampling and initial sorting phase. Sampling activities within the module were organized into three components operating complementary sampling methods. The first component, coordinated by Christophe Daugeron, mostly sampled flying insects, using Malaise traps, interception traps, light traps and hand-netting. The second component, coordinated by Louis Deharveng, mainly sampled soil invertebrates, using pitfall traps, extraction with Berlese funnels and hand collecting. The third component, coordinated by Olivier Gargominy, was devoted to snails. Several participants also worked independently in the field and contributed to the collective approach of the module by surveying reference sites and identifying the material obtained.

The first step after sampling consisted of sorting specimens into the different classes and orders of invertebrates. This timeconsuming task was supported during three years by specific conventions with the MNP, the Collections Service of the MNHN and the Systematics and Evolution Department of the MNHN. It was carried out by dedicated temporary staff with a good knowledge of general insect taxonomy, under the supervision of group coordinators.

Second sorting phase and identification. While each sampling method is most efficient for a certain type of invertebrates, it can also yield significant proportions of non-target species.
TABLE 1. - Terrestrial Invertebrates Module of the Mercantour/Alpi Marittime ATBI: taxonomic coverage and taxonomists involved, Occasional contributors in square brackets.

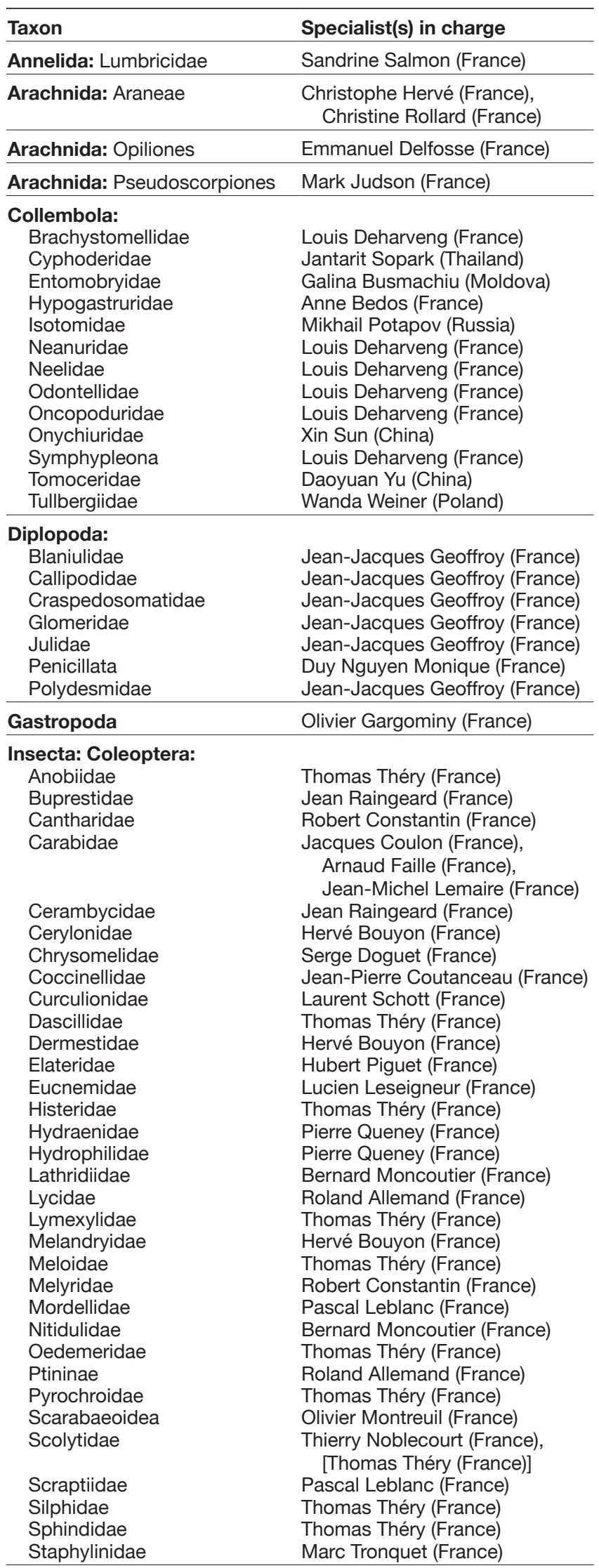




\begin{tabular}{|c|c|}
\hline Taxon & Specialist(s) in charge \\
\hline $\begin{array}{l}\text { Insecta: Coleoptera: } \\
\text { Tenebrionidae } \\
\\
\text { Tetratomidae } \\
\text { Throscidae } \\
\text { Trogositidae }\end{array}$ & $\begin{array}{l}\text { Hervé Bouyon (France), } \\
\text { [Thomas Théry (France)] } \\
\text { Hervé Bouyon (France) } \\
\text { Lucien Leseigneur (France) } \\
\text { Thomas Théry (France) }\end{array}$ \\
\hline Insecta: Dermaptera: Forficulidae & e Thomas Théry (France) \\
\hline $\begin{array}{l}\text { Insecta: Diptera: } \\
\text { Acroceridae } \\
\text { Bombyliidae } \\
\text { Conopidae } \\
\\
\text { Dolichopodidae } \\
\text { Drosophilidae } \\
\text { Empidinae } \\
\\
\text { Pipunculidae } \\
\text { Stratiomyidae } \\
\text { Syrphidae } \\
\text { Tachinidae } \\
\end{array}$ & $\begin{array}{l}\text { Patrice Leraut (France) } \\
\text { Patrice Leraut (France) } \\
\text { Axel Ssymank (Germany), } \\
\text { [Patrice Leraut (France)] } \\
\text { Marc Pollet (Belgium) } \\
\text { Jean David (France) } \\
\text { Christophe Daugeron (France), } \\
\text { [Vincent Lefebvre (France)] } \\
\text { Christian Kehlmaier (Germany) } \\
\text { Axel Ssymank (Germany) } \\
\text { Axel Ssymank (Germany) } \\
\text { Patrice Leraut (France) }\end{array}$ \\
\hline $\begin{array}{l}\text { Insecta: Hemiptera: } \\
\text { Auchenorrhyncha } \\
\text { Cicadellidae } \\
\text { Coccoidea } \\
\text { Psyllidae } \\
\end{array}$ & $\begin{array}{l}\text { Adeline Soulier-Perkins (France) } \\
\text { Gernot Kunz (Austria) } \\
\text { Danièle Matile (France) } \\
\text { David Ouvrard (France) }\end{array}$ \\
\hline Insecta: Heteroptera: Miridae & Armand Matocq (France) \\
\hline $\begin{array}{l}\text { Insecta: Hymenoptera: } \\
\text { Apidae } \\
\text { Cynipoidea } \\
\text { Dryinidae } \\
\text { Formicidae } \\
\text { Ichneumonidae } \\
\text { Pompilidae }\end{array}$ & $\begin{array}{l}\text { Franck Muller (France) } \\
\text { Juli Pujade-Villars (Spain) } \\
\text { Massimo Olmi (Italy) } \\
\text { Anthony Turpaud (France), } \\
\text { Quentin Rome (France) } \\
\text { Claire Villemant (France), } \\
\text { Takuma Yoshida (Japan) } \\
\text { Frédéric Durand (France) }\end{array}$ \\
\hline
\end{tabular}

Thus, Malaise and interception traps provided, in addition to a huge number of flying insects, many wingless invertebrates (such as arachnids, springtails, insect larvae and ants) that belong to taxonomic groups that are largely represented in the soil. The second step in the sorting tasks was therefore organized differently from the first, with coordinators being appointed for each order or class. Under their supervision, and irrespective of the sampling method, specimens were sorted to operational taxonomic levels for identification, depending on the availability of specialists for the groups concerned. For example, sorting was carried out to family or superfamily for beetles, where specialists usually focus on only one or a few families, and to ordinal level for arachnids (except mites) and myriapods, where specialists usually deal with one or more orders.

Barcoding. DNA barcoding was used to complement traditional taxonomic methods and investigate the possible presence of cryptic species or differentiation between populations. After identification and databasing of associated information, selected specimens were transmitted to the SSM for extraction and sequencing (see section "Processing specimens for barcoding").

\begin{tabular}{ll}
\hline Taxon & Specialist(s) in charge \\
\hline $\begin{array}{l}\text { Insecta: Hymenoptera: } \\
\text { Sphecidae }\end{array}$ & Pierre Tripotin (France) \\
Symphyte & David R. Smith (USA) \\
Vespidae & Quentin Rome (France), \\
& [Phil Lester (New Zealand)] \\
\hline Insecta: Lepidoptera: & Patrice Leraut (France) \\
Amphisbatidae & Patrice Leraut (France) \\
Arctiidae & Patrice Leraut (France) \\
Coleophoridae & Patrice Leraut (France) \\
Crambidae & Patrice Leraut (France) \\
Epermeniidae & Patrice Leraut (France) \\
Gelechiidae & Antoine Lévêque (France), \\
Geometridae & [Patrice Leraut (France)] \\
& Patrice Leraut (France) \\
Lycaenidae & Patrice Leraut (France) \\
Momphidae & Jérome Barbut (France), \\
Noctuidae & [Patrice Leraut (France)] \\
& Patrice Leraut (France) \\
Nymphalidae & Patrice Leraut (France) \\
Oecophoridae & Patrice Leraut (France) \\
Plutellidae & Patrice Leraut (France) \\
Prodoxidae & Patrice Leraut (France) \\
Pterophoridae & Patrice Leraut (France) \\
Pyralidae & Patrice Leraut (France) \\
Scythridae & Patrice Leraut (France) \\
Sesiidae & Patrice Leraut (France) \\
Tortricidae & Patrice Leraut (France) \\
Yponomeutidae & Pierre Tillier (France) \\
\hline Insecta: Mecoptera & Pierre Tillier (France) \\
\hline Insecta: Neuroptera & Pierre Tillier (France) \\
\hline Insecta: Rhaphidioptera & Hans Pohl (Germany) \\
\hline Insecta: Strepsiptera & \\
\hline Insecta: Trichoptera: & Patrice Leraut (France) \\
Limnephilidae & Patrice Leraut (France) \\
Philopotamidae & \\
\hline & \\
&
\end{tabular}

Data management. In addition to supervising the second sorting step for their group, each coordinator had to: 1) organize the dispatching of specimens to relevant specialists for identification; 2) recover identifications and specimens; 3) manage and clean datasets in the project database; 4) extract and send validated subsets of data to the INPN database; 5) send specimens of the target groups for barcoding and 6) deposit specimens in the collections. The amount of work required for the coordination of these tasks across the different supervisors (Fig. 2), the management and storing of a rapidly increasing amount of material and data of various origins, and dealing with the administrative constraints linked to the conventions that supported our work was grossly underestimated in the initial stages. This led us to rapidly set up basic management rules with a dedicated supervising staff, including standardization of protocols for data communication and specimen storage.

\section{SAMPLING STRATEGY}

Following experience from large biological expeditions, such as Santo 2006 (Bedos, Prié \& Deharveng 2011; Deharveng \& Sémah 2011), and from various campaigns of terrestrial 


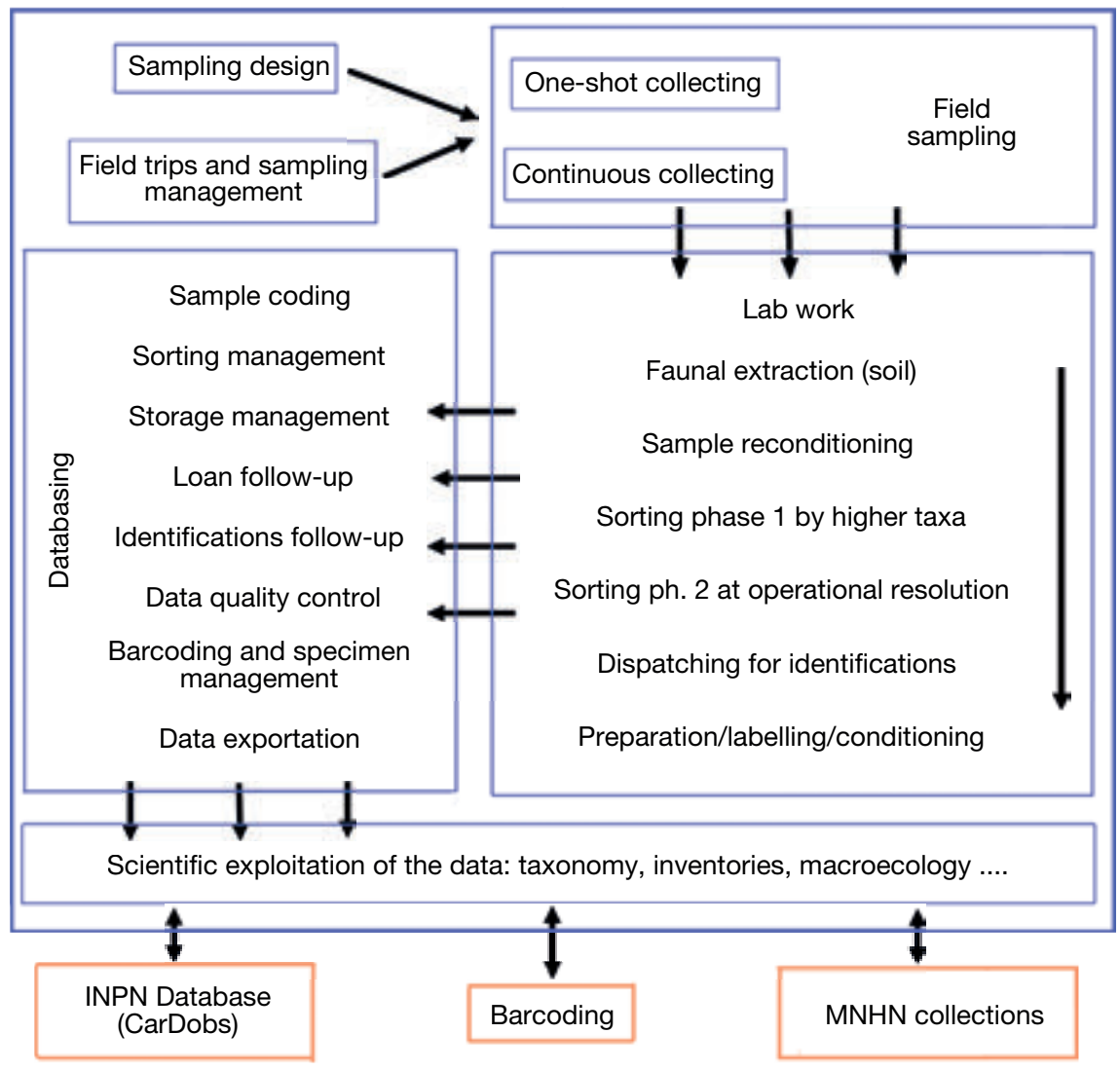

FIG. 2. - Organization of tasks in the module "Terrestrial Invertebrates" of the Mercantour-Alpi Marittime ATBI (blue frame) and connections with the different MNHN services (orange frames).

biodiversity inventory involving multiple participants, we combined two strategies for sampling terrestrial invertebrates: independent sampling to catch the highest possible representation of biodiversity, and standardized sampling to produce comparable datasets.

Independent sampling was carried out by each specialist, who will know better than anyone else which habitats and methods will produce the highest diversity of species for his or her group. However, the drawback of this approach is that it does not allow standardized comparisons between the different groups. Independent sampling is very efficient for the taxa of interest to the specialist, who tends however to ignore other taxa, or at best collects and distributes only some of them to other specialists. During the project, individual collecting was very productive and clearly showed that taxon-driven sampling is essential for completing a faunistic inventory and gathering biological data, in spite of the huge amount of information potentially useful for the inventory that is passed over in the process.

Integrated sampling used several complementary techniques applied to selected sites, in order to obtain a comprehensive representation of the biodiversity at each site, along with quantitative data for comparing biodiversity patterns.

The sampling techniques were standardized, and the sampling design identical at the different sites. All specimens collected were labelled and stored according to a fixed procedure, after which they were sorted for dispatching to relevant specialists (see above). In spite of producing massive collections, the integrated sampling techniques did not include attractive devices (light traps were only used during independent collecting).

\section{SAMPLING TECHNIQUES}

A number of techniques are available for sampling terrestrial invertebrates (Achterberg et al. 2010; Häuser \& Riede 2015). Each has its field of application in terms of the spectrum of taxa sampled, with frequent overlap and different productiveness. Several techniques known for their high efficiency and simplicity were used, in order to cover the maximum number of species and habitats for minimal sampling effort and overlap in the results. They can be grouped into two categories - continuous sampling and one-shot sampling - according to the way in which they were implemented during the project.

\section{Continuous sampling techniques (Fig. 3)}

Contrary to non-insect arthropods and soil insect larvae, most adult insects can fly and have short periods of activity that vary according to the species, from early spring to late autumn. For this reason, continuous sampling was necessary to obtain a correct overview of their diversity, given that our knowledge of the phenology of the species of the southwestern Alps species is very limited. Three sampling methods 
were used to ensure such continuous sampling, with traps changed every 15 days:

1) Malaise traps. These are efficient for flying insects (except Lepidoptera), for epigean Collembola, spiders and harvestmen. The method is well known, robust and extremely productive. It mobilized most of the sorting work of the module.

2) Interception traps. These are efficient for fast-flying insects, especially beetles, which usually fall after hitting an obstacle. They are also very productive, but less so than Malaise traps. The results they gave during the project were uneven.

3) Pitfall traps containing $90 \%$ ethanol. These are efficient for surface soil fauna, particularly spiders, terrestrial isopods, springtails, ants and other insects foraging at ground level, such as ground-beetles. A single pitfall of $1 \mathrm{~cm}$ aperture typically provided $10-20$ species in 15 days. However, the interval between trap changes ( 15 days), imposed by the limited availability of human resources in the field during the sampling season, proved to be too long (see section continuous sampling).

\section{One-shot sampling techniques (Figs 4; 5)}

Such methods do not rely on a permanent device in the field. They can be used periodically at a given site during favourable seasons, provided that sufficient human resources are available. Since this was not the case for our project, they were applied for only one period per site during the three years of the TIM sampling.

1) Extraction of soil cores (leaf litter and underlying soil) using simplified Berlese funnels (Fig. 5). This is the most practical and efficient method for extracting soil arthropods. Because almost all mobile stages of soil arthropods living in a given soil sample are collected, this is the method best suited to standardized approaches. The device used by the TIM consisted of a plastic funnel of $30 \mathrm{~cm}$ diameter, a plastic mesh $(2 \mathrm{~mm}$ mesh size, with a few larger holes added peripherally) placed slightly below the rim of the funnel, and a reception vial half-filled with $95 \%$ ethanol placed under its stem. The freshly sampled soil core is placed on the grid and it dries progressively from its top, causing motile arthropods to pass through the mesh and fall into the vial below. This technique was widely used during the project. The extraction was performed in a dry room, but no light was placed above the sample to avoid killing sensitive specimens before they could fall into the vial. A set of 50 Berlese funnels was run simultaneously.

2) Soil flotation. This is used instead of Berlese extraction when soil is too humid or contains a high proportion of fine mineral grains. The substrate is washed in a plastic basin and floating arthropod specimens (mostly Collembola) are picked up with a small brush. Alternatively, all floating material can be skimmed off with a fine net and re-processed with a Berlese funnel. Non-floating arthropods (e.g. terrestrial isopods) are not obtained using this method. This technique was occasionally used during the project.

3) Litter sifting. Sifting litter on a tray or using a Winkler apparatus is an efficient technique for concentrating the fauna. Specimens are collected directly from the sifted debris, or else the debris is re-processed using a Berlese funnel. This technique was largely used during the project for small snails and low-density arthropods, such as pseudoscorpions.

4) Vegetation beating and sweep-netting. Beating plants, branches or shrubs on a white sheet or tray and sweeping grasses with a net are the best methods for collecting species living on the vegetation, which includes many winged insects, as well as arachnids and springtails. Specimens are collected directly from the tray, or the debris obtained is re-processed on Berlese funnel. This technique was occasionally used during the project, particularly for spiders.

5) Light traps. Light trapping is the most productive collecting method for moths and certain other groups of flying insects. It was operated by individual taxonomists and only moths were collected. It was the only "attractive method" employed during the project. Since it was not used intensively, it is unlikely to have had a significant impact on the local diversity of moths.

6) Lumbricidae collecting. Earthworms were collected by hand-picking after digging with a spade a surface of $0.1 \mathrm{~m}^{2}$ delimited using a metal cylinder, since the chemicals usually used to expel earthworms from soil are not allowed in the MNP.

7) Hand collecting. This consists of searching for animals "by sight" under stones, logs or the bark of living trees. The animals found in this way are collected using a pooter (aspirator), a fine brush dipped in alcohol or, if they are large enough, by simply picking them up with fingers. Such methods are useful for the rapid collection of groups such as snails, millipedes, large arachnids, isopods, Diplura, large Collembola and various insects, and it can provide species not obtained with other methods (e.g. corticolous pseudoscorpions). Visual searches are also useful for selecting substrates for subsequent extraction on Berlese funnels (e.g. rotting wood containing Collembola). Since most of the nationally notable species of snails present in the Mercantour Park are of large or very large size, hand collecting was largely favoured for this group, particularly in the context of cooperation with the park guards assisting with the collecting.

\section{Missing sampling techniques}

The selection of sampling techniques was based on the following criteria: proven productivity, complementarity, ease of implementation, minimal environmental impact, financial viability and the availability of specialists to operate them. Several methods were not adopted because they have very restricted applications (concerning only a minor component of the fauna), examples being chemical attractants like pheromonal traps. Others were excluded because they were not allowed in the protected area under study, an obvious example being fogging with insecticides. One method that could have provided access to important additional components of arthropod biodiversity is acoustic surveying, but this was not employed by the TIM due to the unavailability of a dedicated specialist during the project. Metabarcoding is also a promising tool for biodiversity inventorying, but this technique is not yet fully operational for routine sampling and it currently lacks adequate DNA reference libraries. 

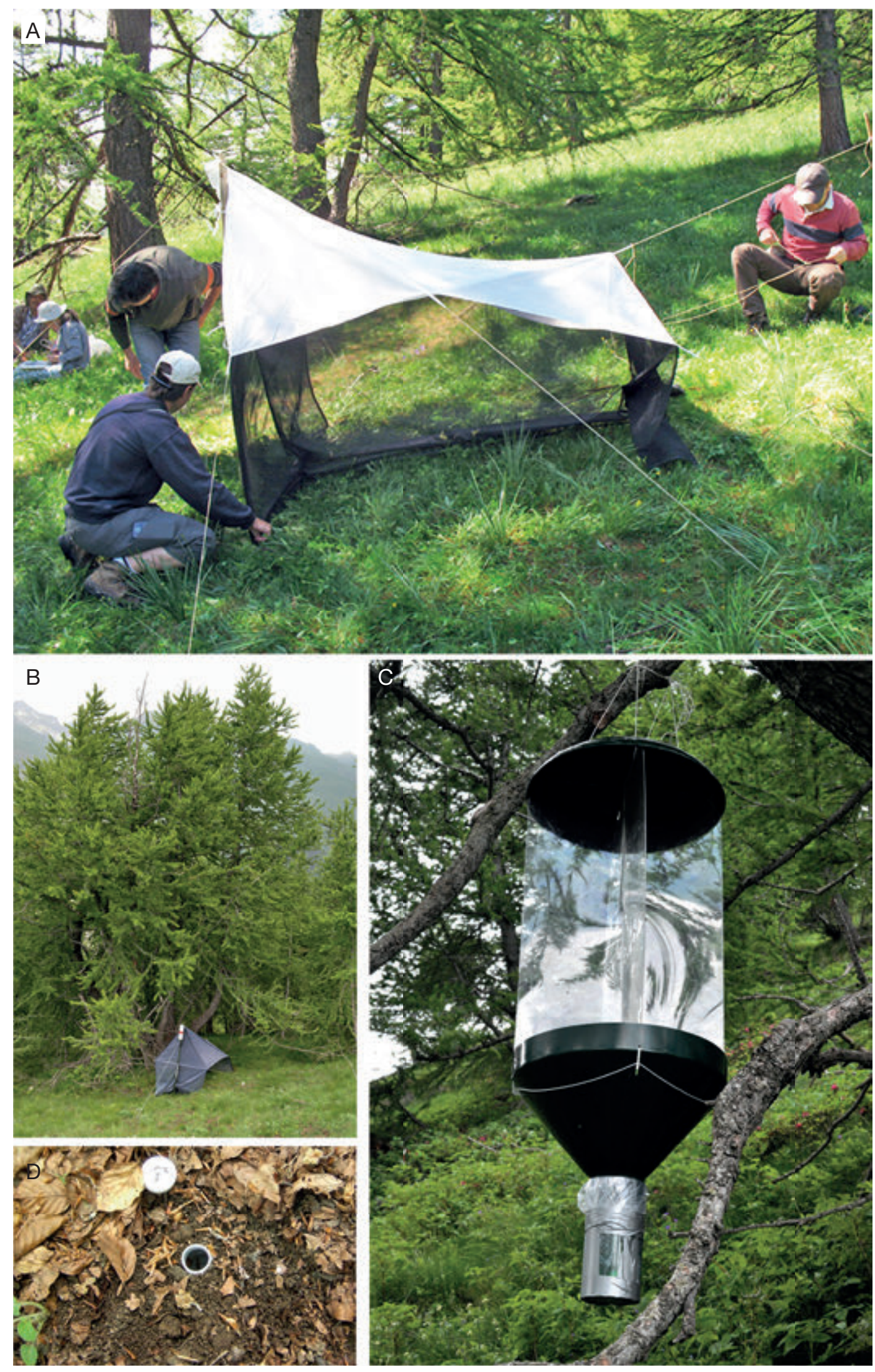

FIG. 3. - Continuous collecting devices: A, Malaise trap (Larche, 2000 m); B, Malaise trap (Caïros, 2000 m); C, interception trap (Caïros, 2000 m); D, pitfall trap (Cairros, 1400 m). Photographs: A, Emmanuel Delfosse; B, C, Quentin Rome; D, Louis Deharveng. 

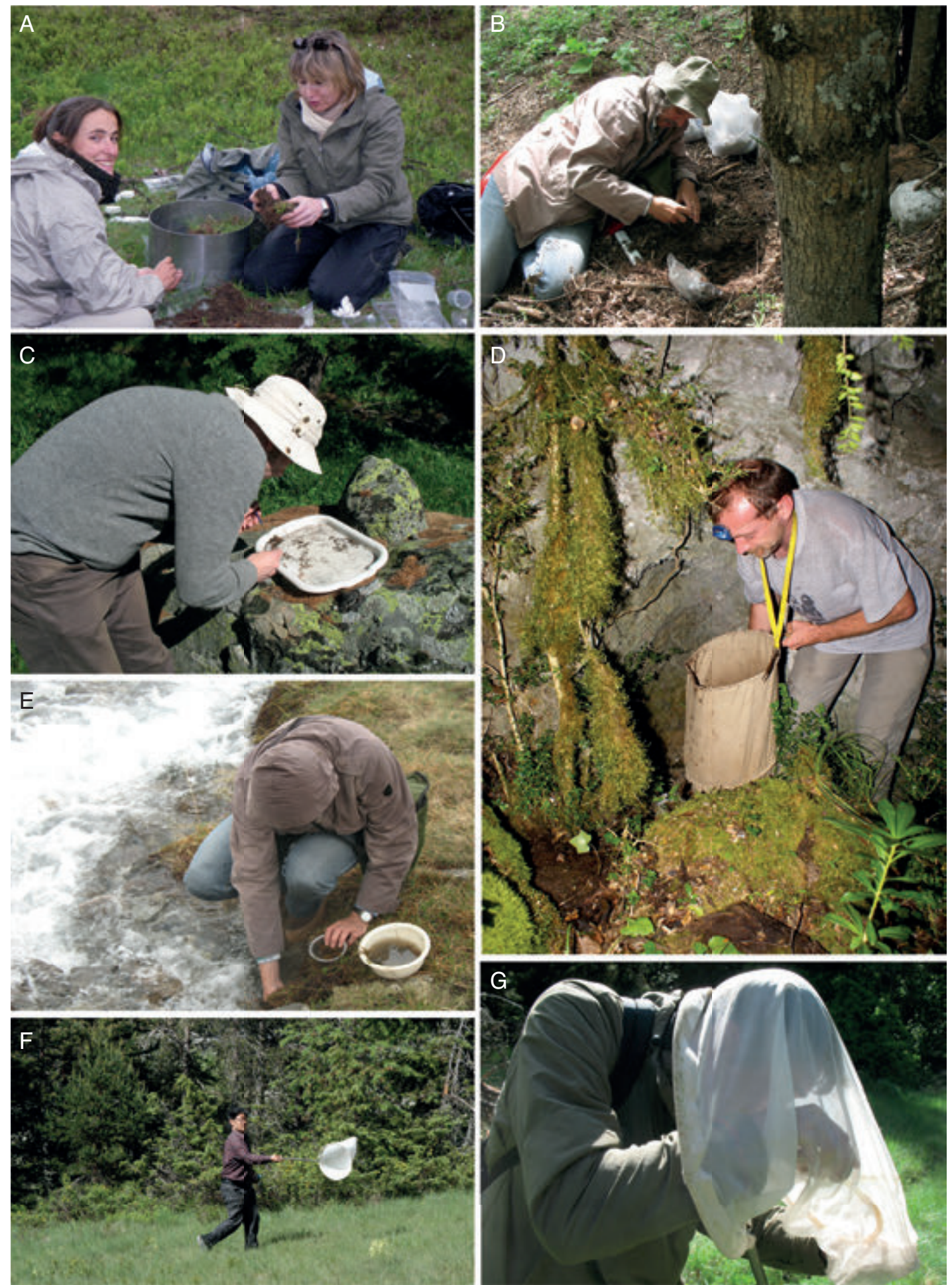

FIG. 4. - One-shot sampling methods: A, earthworm collecting from core sample; B, collecting soil sample for Berlese extraction; C, sifting and hand collecting with a fine brush from residues; D, litter sifting; E, soil flotation; F, G, hand-netting. Photographs: A, Louis Deharveng; B, C, E, G, Donghui Wu; D, Olivier Gargominy; F, Christophe Daugeron.

SAMPLING SITES (Fig. 6)

Sampling sites for the independent sampling strategy were freely selected by the specialist concerned. As a result, they are irregularly scattered within the MNP.

For the integrated sampling, the rationale for site selection was a balance between pure inventory objectives for maximizing sample diversity, and ecological objectives that required duplicates and standardization. Two major gradients shape biodiversity patterns in the southwestern Alps: the latitudinal gradient of increasing species richness from north to south, partly explained by last glaciation influence (Médail \& Diadema 2009), and the altitudinal gradient, typical of mountainous regions. The multi-taxon 


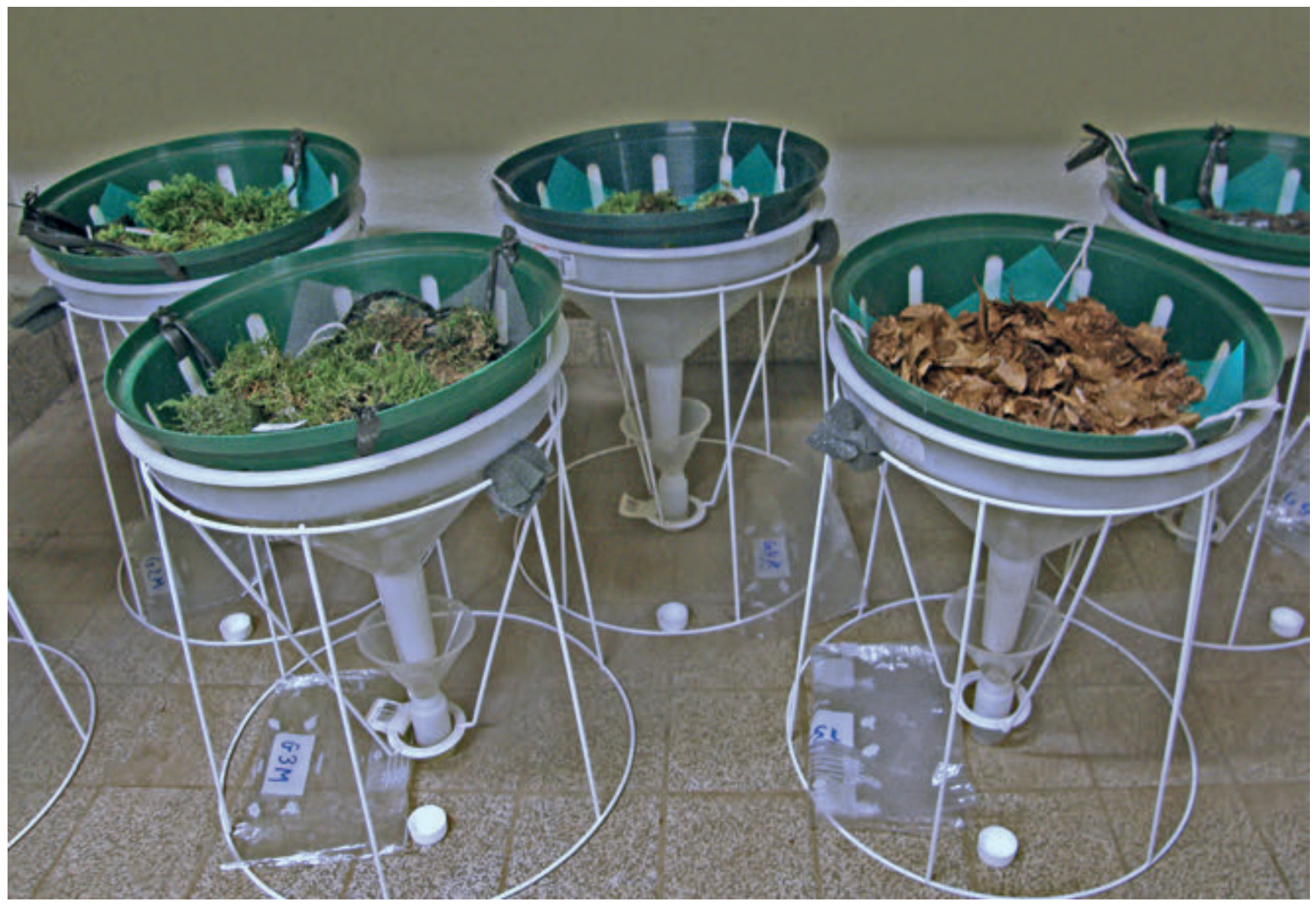

FIG. 5. - Extraction of litter sample using Berlese funnels. Photograph: Louis Deharveng.

approach adopted by the TIM represented an attempt to test and illustrate these gradients, which had not been documented previously for such a large array of zoological groups. Sampling effort was equally distributed in four valleys, arranged along the latitudinal gradient from north to south: the Larche valley in Ubaye, the Sestrière valley in Haute-Tinée, the Salèse valley near Le Boréon, connected to the larger Vésubie valley, and the Cairos valley, connected to the larger La Roya valley (Fig. 6; Tables 2, 3). In each valley, two sites were chosen, one at 1400-1500 m and one at $2000 \mathrm{~m}$. Sites at the same altitude were located in similar vegetation types. It was initially planned to sample the four valleys during the same season. This idea was scientifically sound, but proved to be unrealistic given the financial and human resources available. We therefore had to divide the fieldwork over three years: 2009 (Boréon and Sestrière), 2010 (Caïros) and 2011 (Larche).

SAMPLING DESIGN AT REFERENCE SITES

An integrated sampling design was applied to eight sites, which were equipped with the same set of sampling devices and were sampled following the same protocols.

\section{Continuous sampling}

The samples of this category obtained during the project are listed in Table 2A. The MNP placed moderate constraints on the positioning of traps: they had to be not too visible from public paths; the liquid preservative of the device should be non-toxic for humans, not strongly coloured and, when employed in large amounts (interception traps), inaccessible to cattle and children. The following traps were used at each site and altitude:

- two Malaise traps, placed 80-120 metres apart;

- one or two interception traps;

- five pitfall traps randomly positioned in a $1 / 2$ ha area.

Every two weeks, staff of the MNP emptied and refilled traps with 90\% ethanol (Malaise and pitfall traps) or with glycol (interception traps), from spring to autumn of each year. The collection duration varied from year to year, depending on the climatic conditions (mainly snowfall) at the beginning and end of the sampling period (Table 2). After topping-up the levels of preserving fluid when necessary, the samples were sent within one week to the MNHN. A few samples were not recovered in time because of bad weather conditions and others were destroyed by cows or humans, but overall $90 \%$ of the samples were retrieved. However, a significant proportion of pitfall traps contained damaged specimens because their contents had decomposed (due to rain dilution, high temperatures or too long intervals between changing traps). The use of monopropylene glycol was considered, but it would have posed other problems, since Collembola, the dominant 


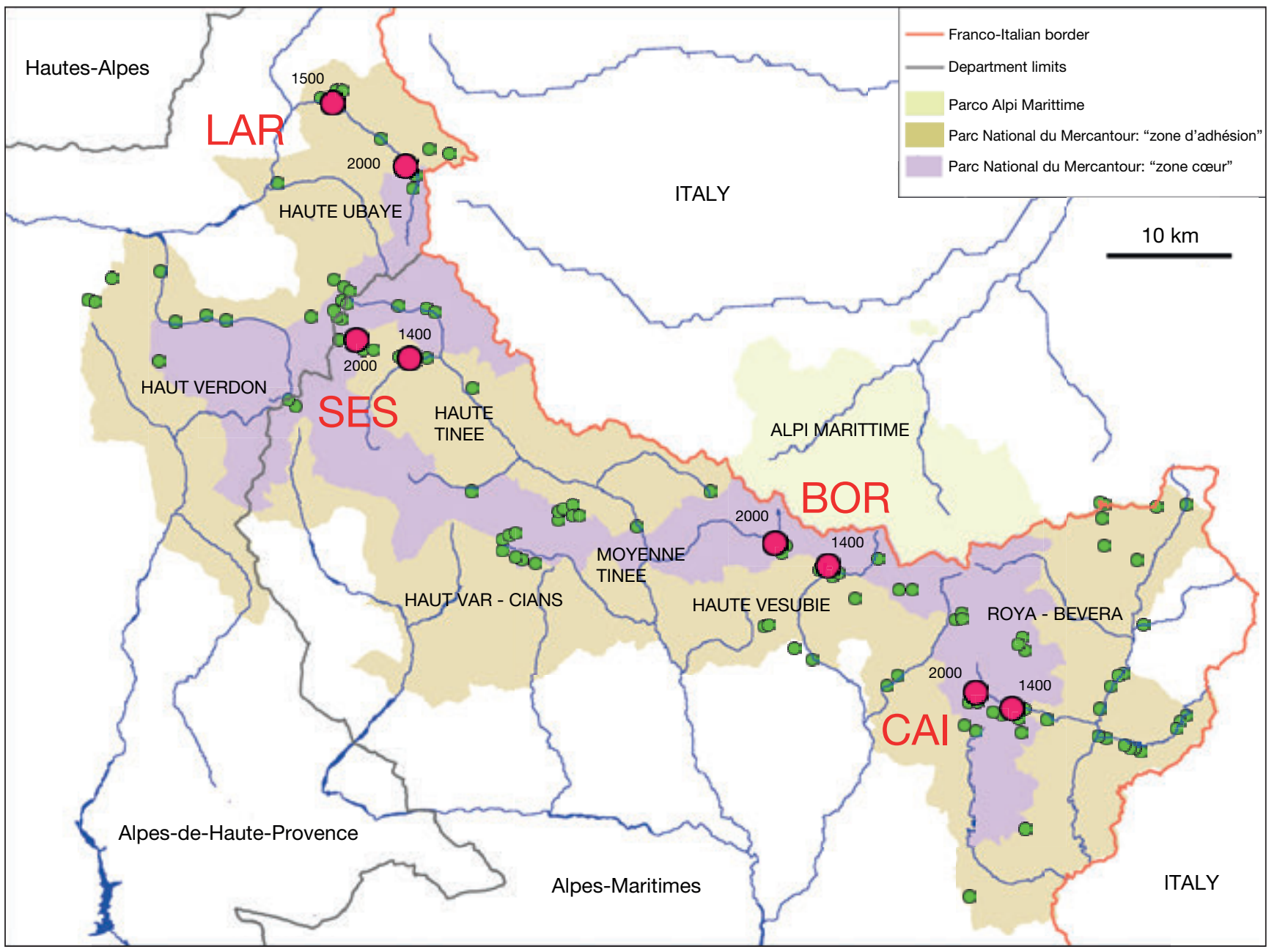

FIG. 6. - Map of TIM sampling sites: O, reference sites of the standardized sampling; o, other sampling sites; BOR, Boreon valley; CAI, Caïros valley; LAR, Larche valley; SES, Sestrière valley.

group in pitfalls, are more liable to float at its surface than with ethanol.

\section{Standardized one-shot sampling}

The samples of this category obtained during the project are listed in Table 3. One-shot sampling of similar intensity was performed at each site within an area of $1 / 2 \mathrm{ha}$, using the same array of techniques, mostly in spring during the first visit to the site. These consisted of:

- five leaf litter samples and five underlying soil samples, each of $250 \mathrm{~cm}^{3}$, to a depth of five $\mathrm{cm}$ for the soil layer;

- two earthworm collections (from Sestrière $1400 \mathrm{~m}$, Sestrière 2000 m, Boréon $1400 \mathrm{~m}$ and Boréon 2000 m).

\section{Non-standardized one-shot sampling at reference sites}

Other techniques, described above in the section "One-shot sampling techniques", were also used at some or all of the reference sites, within a radius of about one ha and without particular periodicity: non-standard soil core sampling, soil flotation, litter sifting, vegetation beating, sweep-netting, light-trapping and hand collecting of earthworms, terrestrial snails and arthropods. These unconstrained samplings often concerned habitats not included in the standardized design, such as humid micro-habitats, tree bark, moss on rocks, and plants locally present at a given site.

\section{DATA AND SPECIMEN MANAGEMENT \\ Coding and labelling}

The information associated with specimens should allow the retrieval of their history, from sampling through the different processing events. Part of this information is often lost in projects of this type due to insufficient or inappropriate labelling, with the result that interesting research opportunities may be missed. For instance, many specimens in national collections are labelled with information on field collection, but without a reference linking them to specimens of other species present in the same field-sample. Thus it would be difficult to exploit such fragmented data for studies of community ecology. By associating each collection specimen with the code of the sample it came from, important information of this type can be saved. The need to retain such information when handling data and specimens was particularly important for our project, which involved many participants and specialists, with a large component of individual sampling. We therefore set up a cod- 
TABLE 2. - A. Coding of standard samples. The complete code of a given sample includes the code of the sampling dates T1 to T9 (see Table 2B for details) before the trap number; Trap samples (M1 and M2: Malaise; IN, IN1 and IN2: interception; PF1 to PF5: pitfall); sampling sites (BOR, Le Boréon; CAI, Caïros; LAR, Larche; SES, Sestrière); altitudes in metres. Multiples $(\times 5)$ in the column "No. samples" indicate the number of sampling replicates when there was more than one in the period.

\begin{tabular}{|c|c|c|c|c|c|c|c|c|c|}
\hline Year & sample codes* & Commune & Locality & Vegetation & Altitude & Longitude & Latitude & $\begin{array}{l}\text { Sampling } \\
\text { period }\end{array}$ & $\begin{array}{c}\text { No. } \\
\text { samples }\end{array}$ \\
\hline 2009 & M09-BOR1400 M1 & $\begin{array}{l}\text { St-Martin- } \\
\text { Vésubie }\end{array}$ & Le Boréon & $\begin{array}{l}\text { Meadow and spruce } \\
\text { forest }\end{array}$ & 1540 & 7.2871439 & 44.1146875 & 11.VI-15.X & 8 (T1-T8) \\
\hline 2009 & M09-BOR1400 M2 & $\begin{array}{l}\text { St-Martin- } \\
\text { Vésubie }\end{array}$ & Le Boréon & $\begin{array}{l}\text { Meadow and spruce } \\
\text { forest }\end{array}$ & 1549 & 7.2890533 & 44.1143415 & 11.VI-15.X & 8 (T1-T8) \\
\hline 2009 & M09-BOR1400 IN & $\begin{array}{l}\text { St-Martin- } \\
\text { Vésubie }\end{array}$ & Le Boréon & $\begin{array}{l}\text { Meadow and spruce } \\
\text { forest }\end{array}$ & 1540 & 7.2871439 & 44.1146875 & 11.VI-15.X & 8 (T1-T8) \\
\hline 2009 & $\begin{array}{l}\text { M09-BOR1400 PF1 } \\
\text { to PF5 }\end{array}$ & $\begin{array}{l}\text { St-Martin- } \\
\text { Vésubie }\end{array}$ & Le Boréon & $\begin{array}{l}\text { Meadow and spruce } \\
\text { forest }\end{array}$ & 1540 & 7.2871439 & 44.1146875 & 11.VI-15.X & $8 \times 5(T 1-T 8)$ \\
\hline 2009 & M09-BOR2000 M1 & Valdeblore & Col de Salèse & $\begin{array}{l}\text { Meadow, } \\
\text { Rhododendrons, } \\
\text { larch and spruce } \\
\text { forest }\end{array}$ & 2058 & 7.23698 & 44.13734 & 10.VI-15.X & 8 (T1-T8) \\
\hline 2009 & M09-BOR2000 M2 & Valdeblore & Col de Salèse & Larch forest & 2032 & 7.2352837 & 44.1388598 & 10.VI-15.X & 8 (T1-T8) \\
\hline 2009 & M09-BOR2000 IN & Valdeblore & Col de Salèse & Larch forest & 2047 & 7.2365699 & 44.1372935 & 10.Vl-15.X & 8 (T1-T8) \\
\hline 2009 & $\begin{array}{l}\text { M09-BOR2000 PF1 } \\
\text { to PF5 }\end{array}$ & Valdeblore & Col de Salèse & Larch forest & 2058 & 7.23698 & 44.13734 & 10.VI-15.X & 8 (T1-T8) \\
\hline 2009 & M09-SES1400 M1 & $\begin{array}{l}\text { St-Dalmas- } \\
\text { le-Selvage }\end{array}$ & $\begin{array}{l}\text { Vallon de } \\
\text { St-Dalmas: La } \\
\text { Buisse }\end{array}$ & $\begin{array}{l}\text { Meadow, broadleaved } \\
\text { and larch forest }\end{array}$ & 1437 & 6.8875257 & 44.2848357 & 9.VI-15.X & 8 (T1-T8) \\
\hline 2009 & M09-SES1400 M2 & $\begin{array}{l}\text { St-Dalmas- } \\
\text { le-Selvage }\end{array}$ & $\begin{array}{l}\text { Vallon de } \\
\text { St-Dalmas: La } \\
\text { Buisse }\end{array}$ & $\begin{array}{l}\text { Meadow, broadleaved } \\
\text { and larch forest }\end{array}$ & 1421 & 6.8867683 & 44.2850731 & 9.VI-15.X & 8 (T1-T8) \\
\hline 2009 & M09-SES1400 IN & $\begin{array}{l}\text { St-Dalmas- } \\
\text { le-Selvage }\end{array}$ & $\begin{array}{l}\text { Vallon de } \\
\text { St-Dalmas: La } \\
\text { Buisse }\end{array}$ & $\begin{array}{l}\text { Meadow, broadleaved } \\
\text { and larch forest }\end{array}$ & 1436 & 6.8876092 & 44.2847834 & 9.VI-15.X & 8 (T1-T8) \\
\hline 2009 & $\begin{array}{l}\text { M09-SES1400 PF1 } \\
\text { to PF5 }\end{array}$ & $\begin{array}{l}\text { St-Dalmas- } \\
\text { le-Selvage }\end{array}$ & $\begin{array}{l}\text { Vallon de } \\
\text { St-Dalmas: La } \\
\text { Buisse }\end{array}$ & $\begin{array}{l}\text { Meadow, broadleaved } \\
\text { and larch forest }\end{array}$ & 1437 & 6.8875257 & 44.2848357 & 9.VI-15.X & $8 \times 5(T 1-T 8)$ \\
\hline 2009 & M09-SES2000 M1 & $\begin{array}{l}\text { St-Dalmas- } \\
\text { le-Selvage }\end{array}$ & Bois de Sestrière & Larch forest & 1966 & 6.8240421 & 44.2927562 & 8.VI-15.X & 8 (T1-T8) \\
\hline 2009 & M09-SES2000 M2 & $\begin{array}{l}\text { St-Dalmas- } \\
\text { le-Selvage }\end{array}$ & Bois de Sestrière & Larch forest & 2011 & 6.8228732 & 44.2925219 & 8.VI-15.X & 8 (T1-T8) \\
\hline 2009 & M09-SES2000 IN & $\begin{array}{l}\text { St-Dalmas- } \\
\text { le-Selvage }\end{array}$ & Bois de Sestrière & Larch forest & 1995 & 6.8235944 & 44.2926706 & 8.VI-15.X & 8 (T1-T8) \\
\hline 2009 & M09-SES2000 PF1 & $\begin{array}{l}\text { St-Dalmas- } \\
\text { le-Selvage }\end{array}$ & Bois de Sestrière & Larch forest & 1966 & 6.8240421 & 44.2927562 & 8.VI-15.X & 8 (T1-T8) \\
\hline 2009 & M09-SES2000 PF2 & $\begin{array}{l}\text { St-Dalmas- } \\
\text { le-Selvage }\end{array}$ & Bois de Sestrière & Larch forest & 1995 & 6.8235944 & 44.2926706 & 8.VI-15.X & 8 (T1-T8) \\
\hline 2009 & M09-SES2000 PF3 & $\begin{array}{l}\text { St-Dalmas- } \\
\text { le-Selvage }\end{array}$ & Bois de Sestrière & Larch forest & 1995 & 6.8235944 & 44.2926706 & 8.VI-15.X & 8 (T1-T8) \\
\hline 2009 & M09-SES2000 PF4 & $\begin{array}{l}\text { St-Dalmas- } \\
\text { le-Selvage }\end{array}$ & Bois de Sestrière & Larch forest & 1973 & 6.8236775 & 44.2927877 & 8.VI-15.X & 8 (T1-T8) \\
\hline 2009 & M09-SES2000 PF5 & $\begin{array}{l}\text { St-Dalmas- } \\
\text { le-Selvage }\end{array}$ & Bois de Sestrière & Larch forest & 2011 & 6.8228732 & 44.2925219 & 8.VI-15.X & 8 (T1-T8) \\
\hline 2010 & M10-CAl1400 M1 & Saorge & $\begin{array}{l}\text { Forêt de Caïros : } \\
\text { Vallerasse }\end{array}$ & Fir forest & 1379 & 7.45615 & 44.00338 & 1.VII-15.X & 7 (T1-T7) \\
\hline 2010 & M10-CAl1400 M2 & Saorge & $\begin{array}{l}\text { Forêt de Caïros : } \\
\text { Vallerasse }\end{array}$ & Fir forest & 1387 & 7.45692 & 44.00343 & 1.VII-15.X & 7 (T1-T7) \\
\hline 2010 & M10-CAl1400 IN & Saorge & $\begin{array}{l}\text { Forêt de Caïros : } \\
\text { Vallerasse }\end{array}$ & Fir forest & 1398 & 7.45577 & 44.00344 & 1.VII-15.X & 7 (T1-T7) \\
\hline 2010 & $\begin{array}{l}\text { M10-CAl1400 PF1 } \\
\text { to PF5 }\end{array}$ & Saorge & $\begin{array}{l}\text { Forêt de Caïros : } \\
\text { Vallerasse }\end{array}$ & Fir forest & 1379 & 7.45615 & 44.00338 & 1.VII-15.X & $7 \times 5$ (T1-T7) \\
\hline 2010 & M10-CAI2000 M1 & Saorge & $\begin{array}{l}\text { Tête de la } \\
\text { Poudrière }\end{array}$ & Larch forest & 1953 & 7.42407 & 44.01454 & 30.VI-15.X & 7 (T1-T7) \\
\hline 2010 & M10-CAI2000 M2 & Saorge & $\begin{array}{l}\text { Tête de la } \\
\text { Poudrière }\end{array}$ & Larch forest & 1992 & 7.42459 & 44.01388 & 30.VI-15.X & 7 (T1-T7) \\
\hline 2010 & M10-CAI2000 IN & Saorge & $\begin{array}{l}\text { Tête de la } \\
\text { Poudrière }\end{array}$ & Larch forest & 1985 & 7.42467 & 44.01400 & 30.VI-15.X & 7 (T1-T7) \\
\hline 2010 & $\begin{array}{l}\text { M10-CAI2000 PF1 } \\
\text { to PF5 }\end{array}$ & Saorge & $\begin{array}{l}\text { Tête de la } \\
\text { Poudrière }\end{array}$ & Larch forest & 1992 & 7.42459 & 44.01388 & 30.VI-15.X & $\begin{array}{c}7 \times 5(\mathrm{~T} 1- \\
\mathrm{T} 7)\end{array}$ \\
\hline 2011 & M11-LAR1500 M1 & Meyronnes & $\begin{array}{l}\text { Right bank of } \\
\text { Ubayette river }\end{array}$ & Larch and ash forest & 1491 & 6.796607 & 44.475409 & 26.V-30.IX & 9 (T1-T9) \\
\hline 2011 & M11-LAR1500 M2 & Meyronnes & $\begin{array}{l}\text { Right bank of } \\
\text { Ubayette river }\end{array}$ & Larch and ash forest & 1491 & 6.796607 & 44.475409 & 26.V-30.IX & 9 (T1-T9) \\
\hline
\end{tabular}


TABLE 2. - Continuation.

\begin{tabular}{|c|c|c|c|c|c|c|c|c|c|}
\hline Year & sample codes* & Commune & Locality & Vegetation & Altitude & Longitude & Latitude & $\begin{array}{c}\text { Sampling } \\
\text { period }\end{array}$ & $\begin{array}{c}\text { No. } \\
\text { samples }\end{array}$ \\
\hline 2011 & M11-LAR1500 IN1 & Meyronnes & $\begin{array}{l}\text { Right bank of } \\
\text { Ubayette river }\end{array}$ & Larch and ash forest & 1491 & 6.796607 & 44.475409 & 26.V-30.IX & 9 (T1-T9) \\
\hline 2011 & M11-LAR1500 IN2 & Meyronnes & $\begin{array}{l}\text { Right bank of } \\
\text { Ubayette river }\end{array}$ & Larch and ash forest & 1491 & 6.796607 & 44.475409 & 26.V-30.IX & 9 (T1-T9) \\
\hline 2011 & $\begin{array}{l}\text { M11-LAR1500 PF1 } \\
\text { to PF5 }\end{array}$ & Meyronnes & $\begin{array}{l}\text { Right bank of } \\
\text { Ubayette river }\end{array}$ & Larch and ash forest & 1491 & 6.796607 & 44.475409 & 26.V-30.IX & $\times 5($ T1-T9) \\
\hline 2011 & M11-LAR2000 M1 & Larche & $\begin{array}{l}\text { W of Col de } \\
\text { Larche: Forêt } \\
\text { de Boisset }\end{array}$ & Larch forest & 1986 & 6.878456 & 44.422731 & 26.V-30.IX & 9 (T1-T9) \\
\hline 2011 & M11-LAR2000 M2 & Larche & $\begin{array}{l}\text { W of Col de } \\
\text { Larche: Forêt } \\
\text { de Boisset }\end{array}$ & Larch forest & 1986 & 6.878456 & 44.422731 & 26.V-30.IX & 9 (T1-T9) \\
\hline 2011 & M11-LAR2000 IN1 & Larche & $\begin{array}{l}\text { W of Col de } \\
\text { Larche: Forêt } \\
\text { de Boisset }\end{array}$ & Larch forest & 1986 & 6.878456 & 44.422731 & 26.V-30.IX & 9 (T1-T9) \\
\hline 2011 & M11-LAR2000 IN2 & Larche & $\begin{array}{l}\text { W of Col de } \\
\text { Larche: Forêt } \\
\text { de Boisset }\end{array}$ & Larch forest & 1986 & 6.878456 & 44.422731 & 26.V-30.IX & 9 (T1-T9) \\
\hline 2011 & $\begin{array}{l}\text { M11-LAR2000 PF1 } \\
\text { to PF5 }\end{array}$ & Larche & $\begin{array}{l}\text { W of Col de } \\
\text { Larche: Forêt } \\
\text { de Boisset }\end{array}$ & Larch forest & 1986 & 6.878456 & 44.422731 & 26.V-30.IX & $9 \times 5$ (T1-T9) \\
\hline
\end{tabular}

TABLE 2. - B. Codes and dates of the successive sampling periods for each sampling site.

\begin{tabular}{|c|c|c|c|c|c|c|c|c|c|c|}
\hline Year & Site & T1 & T2 & T3 & T4 & T5 & T6 & T7 & T8 & T9 \\
\hline 2009 & BOR1400 & 11.VI-24.VI & 24.VI-9.VII & 9.VII-24.VII & 24.VII-13.VIII & 13.VIII-27.VIII & 27.VIII-18.IX & 18.IX-5.X & 5.X-15.X & - \\
\hline 2009 & BOR2000 & 10.VI-24.VI & 24.VI-9.VII & 9.VII-24.VII & 24.VII-13.VIII & 13.VIII-27.VIII & 27.VIII-18.IX & 18.IX-5.X & 5.X-15.X & - \\
\hline 2009 & SES1400 & 9.VI-30.VI & 30.VI-10.VII & 10.VII-23.VII & 23.VII-7.VIII & 7.VIII-19.VIII & 19.VIII-22.IX & 22.IX-7.X & 7.X-15.X & - \\
\hline 2009 & SES2000 & 8.VI-24.VI & 24.VI-10.VII & 10.VII-23.VII & 23.VII-7.VIII & 7.VIII-19.VIII & 19.VIII-22.IX & 22.IX-7.X & 7.X-15.X & - \\
\hline 2010 & CAI1400 & 1.VII-16.VII & 16.VII-31.VII & 31.VII-16.VIII & 16.VIII-30.VIII & 30.VIII-15.IX & 15.IX-30.IX & 30.IX-15.X & - & - \\
\hline 2010 & CAI2000 & 30.VI-16.VII & 16.VII-31.VII & 31.VII-16.VIII & 16.VIII-30.VIII & 30.VIII-15.IX & 15.IX-30.IX & $30.1 X-15 . X$ & - & - \\
\hline 2011 & LAR1500 & 26.V-9.VI & 9.VI-24.VI & 24.VI-8.VII & 8.VII-22.VII & 22.VII-5.VIII & 5.VIII-19.VIII & 19.VIII-2.IX & 2.IX-16.IX & - \\
\hline 2011 & LAR2000 & 26.V-9.VI & 9.VI-24.VI & 24.VI-8.VII & 8.VII-22.VII & 22.VII-5.VIII & 5.VIII-19.VIII & 19.VIII-2.IX & 2.IX-16.IX & 16.IX-30.IX \\
\hline
\end{tabular}

ing system covering all biological material and information gathered by TIM participants. The codes assigned to samples in the project (project codes) were of two forms:

1) for Malaise and interception traps, which concerned many taxonomists and were installed/operated by several persons, the code of each sample was constituted by a prefix including the sampling year, followed by site abbreviation, device number and period number (Table 2);

2) for other standardized samples and for individual samples, linked to one or a few taxonomists, the project-code consisted of a prefix formed from the exact day of collection (the last day of the collection event if it extended over more than one day), and a suffix formed from the initials of the name(s) of the collector(s) + the number of the sample in the sampling day. Examples can be seen in Table 3. The initials of the collector name are replaced by next letter of the name or surname when they duplicate existing initials.

\section{Sorting and storing (Fig. 7)}

The large number of specimens and species obtained through standard sampling and notably with Malaise traps introduces a heavy workload for sorting the collected material and requires an efficient organisation for the dispatching of specimens to specialists and the management of identifications.

Material in alcohol was sorted to class, order or family level, depending on the taxonomic group, using a binocular microscope, according to the workflow outlined above. All specimens of each group from each sample were placed in a vial. The vials for a given zoological group from different samples were placed together in a jar or a plastic box and stored either at room temperature, or for groups selected for barcoding, at $5^{\circ} \mathrm{C}$ in a refrigerator.

Group coordinators then sent the material in their charge for identification to relevant specialists (when available), accompanied by a form that specified the conditions of the loan (duration, material to be returned, conditions for molecular studies). Most of the studied insect specimens were mounted and labelled by the specialist who identified them. Part of this material, notably holotype specimens, was returned and stored in the MNHN collections while the rest remained at specialist's disposal.

\section{Processing specimens for barcoding}

Selection of specimens for barcoding was made during the second phase of the sorting process. Each specimen to be 
TABLE 3. - Soil and litter samples. For those marked «(earthworms)» in the last column only earthworms were collected. Altitudes are in metres. Abbreviations: DB, Deharveng \& Bedos; SS, Sandrine Salmon.

\begin{tabular}{|c|c|c|c|c|c|c|c|c|c|}
\hline Year & sample codes & Commune & Locality & Vegetation & Altitude & Longitude & Latitude & $\begin{array}{l}\text { Sampling } \\
\text { date }\end{array}$ & No. samples \\
\hline 2009 & $\begin{array}{l}\text { M090611-DB01 } \\
\text { to DB10 }\end{array}$ & $\begin{array}{l}\text { St-Martin- } \\
\text { Vésubie }\end{array}$ & Le Boréon & $\begin{array}{l}\text { Meadow and spruce } \\
\text { forest }\end{array}$ & 1540 & 7.2871439 & 44.1146875 & 11.6 .09 & 10 \\
\hline 2009 & M090611-SS01 & $\begin{array}{l}\text { St-Martin- } \\
\text { Vésubie }\end{array}$ & Le Boréon & $\begin{array}{l}\text { Meadow and spruce } \\
\text { forest }\end{array}$ & 1540 & 7.2871439 & 44.1146875 & 11.6.09 & $\begin{array}{l}1 \text { (earth- } \\
\text { worms) }\end{array}$ \\
\hline 2009 & M090611-SS03 & $\begin{array}{l}\text { St-Martin- } \\
\text { Vésubie }\end{array}$ & Le Boréon & $\begin{array}{l}\text { Meadow and spruce } \\
\text { forest }\end{array}$ & 1528 & 7.2891678 & 44.1146812 & 11.6 .09 & $\begin{array}{l}1 \text { (earth- } \\
\text { worms) }\end{array}$ \\
\hline 2009 & $\begin{array}{l}\text { M090610-DB01 } \\
\text { to DB10 }\end{array}$ & $\begin{array}{l}\text { St-Martin- } \\
\text { Vésubie }\end{array}$ & Col de Salèse & $\begin{array}{l}\text { Meadow, } \\
\text { Rhododendrons, } \\
\text { larch and spruce } \\
\text { forest }\end{array}$ & 2058 & 7.23698 & 44.13734 & 10.6.09 & 10 \\
\hline 2009 & M090610-SS01 & $\begin{array}{r}\text { St-Martin- } \\
\text { Vésubie }\end{array}$ & Col de Salèse & $\begin{array}{l}\text { Meadow, } \\
\text { Rhododendrons, } \\
\text { larch and spruce } \\
\text { forest }\end{array}$ & 2058 & 7.23698 & 44.13734 & 10.6.09 & $\begin{array}{l}1 \text { (earth- } \\
\text { worms) }\end{array}$ \\
\hline 2009 & M090610-SS04 & $\begin{array}{l}\text { St-Martin- } \\
\text { Vésubie }\end{array}$ & Col de Salèse & $\begin{array}{l}\text { Meadow, } \\
\text { Rhododendrons, } \\
\text { larch and spruce } \\
\text { forest }\end{array}$ & 2025 & 7.2355672 & 44.1380491 & 10.6.09 & $\begin{array}{l}1 \text { (earth- } \\
\text { worms) }\end{array}$ \\
\hline 2009 & $\begin{array}{l}\text { M090609-DB01 } \\
\text { to DB10 }\end{array}$ & $\begin{array}{l}\text { St-Dalmas- } \\
\text { le-Selvage }\end{array}$ & $\begin{array}{l}\text { Vallon de } \\
\text { St-Dalmas: } \\
\text { La Buisse }\end{array}$ & $\begin{array}{l}\text { Meadow, broadleaved } \\
\text { and larch forest }\end{array}$ & 1437 & 6.8875257 & 44.2848357 & 9.6 .09 & 10 \\
\hline 2009 & M090609-SS03 & $\begin{array}{l}\text { St-Dalmas- } \\
\text { le-Selvage }\end{array}$ & $\begin{array}{l}\text { Vallon de } \\
\text { St-Dalmas: } \\
\text { La Buisse }\end{array}$ & $\begin{array}{l}\text { Meadow, broadleaved } \\
\text { and larch forest }\end{array}$ & 1434 & 6.8872525 & 44.2848239 & 9.6 .09 & $\begin{array}{l}1 \text { (earth- } \\
\text { worms) }\end{array}$ \\
\hline 2009 & M090609-SS05 & $\begin{array}{l}\text { St-Dalmas- } \\
\text { le-Selvage }\end{array}$ & $\begin{array}{l}\text { Vallon de } \\
\text { St-Dalmas: } \\
\text { La Buisse }\end{array}$ & $\begin{array}{l}\text { Meadow, broadleaved } \\
\text { and larch forest }\end{array}$ & 1421 & 6.8867683 & 44.2850731 & 9.6 .09 & $\begin{array}{l}1 \text { (earth- } \\
\text { worms) }\end{array}$ \\
\hline 2009 & $\begin{array}{l}\text { M090608-DB01 } \\
\text { \& DB02 }\end{array}$ & $\begin{array}{l}\text { St-Dalmas- } \\
\text { le-Selvage }\end{array}$ & Bois de Sestrière & Larch forest & 1966 & 6.8240421 & 44.2927562 & 8.6 .09 & 2 \\
\hline 2009 & $\begin{array}{l}\text { M090608-DB03 } \\
\text { \& DB04 }\end{array}$ & $\begin{array}{l}\text { St-Dalmas- } \\
\text { le-Selvage }\end{array}$ & Bois de Sestrière & Larch forest & 1995 & 6.8235944 & 44.2926706 & 8.6.09 & 2 \\
\hline 2009 & $\begin{array}{l}\text { M090608-DB05 } \\
\text { \& DB06 }\end{array}$ & $\begin{array}{l}\text { St-Dalmas- } \\
\text { le-Selvage }\end{array}$ & Bois de Sestrière & Larch forest & 1995 & 6.8235944 & 44.2926706 & 8.6 .09 & 2 \\
\hline 2009 & $\begin{array}{l}\text { M090608-DB07 } \\
\text { \& DB08 }\end{array}$ & $\begin{array}{l}\text { St-Dalmas- } \\
\text { le-Selvage }\end{array}$ & Bois de Sestrière & Larch forest & 1973 & 6.8236775 & 44.2927877 & 8.6.09 & 2 \\
\hline 2009 & $\begin{array}{l}\text { M090608-DB09 } \\
\text { \& DB10 }\end{array}$ & $\begin{array}{l}\text { St-Dalmas- } \\
\text { le-Selvage }\end{array}$ & Bois de Sestrière & Larch forest & 2011 & 6.8228732 & 44.2925219 & 8.6 .09 & 2 \\
\hline 2009 & M090608-SS01 & $\begin{array}{l}\text { St-Dalmas- } \\
\text { le-Selvage }\end{array}$ & Bois de Sestrière & Larch forest & 1973 & 6.8236775 & 44.2927877 & 8.6.09 & $\begin{array}{l}1 \text { (earth- } \\
\text { worms) }\end{array}$ \\
\hline 2009 & M090608-SS02 & $\begin{array}{l}\text { St-Dalmas- } \\
\text { le-Selvage }\end{array}$ & Bois de Sestrière & Larch forest & 2011 & 6.8228732 & 44.2925219 & 8.6 .09 & $\begin{array}{l}1 \text { (earth- } \\
\text { worms) }\end{array}$ \\
\hline 2010 & $\begin{array}{l}\text { M100701-DB01 } \\
\text { to DB04 }\end{array}$ & Saorge & $\begin{array}{l}\text { Forêt de Caïros : } \\
\text { Vallerasse }\end{array}$ & Fir forest & 1379 & 7.45615 & 44.00338 & 1.7.10 & 4 \\
\hline 2010 & $\begin{array}{l}\text { M100701-DB05 } \\
\text { to DB10 }\end{array}$ & Saorge & $\begin{array}{l}\text { Forêt de Caïros : } \\
\text { Vallerasse }\end{array}$ & Fir forest & 1398 & 7.45577 & 44.00344 & 1.7.10 & 6 \\
\hline 2010 & $\begin{array}{l}\text { M100630-DB01 } \\
\text { to DB10 }\end{array}$ & Saorge & $\begin{array}{l}\text { Tête de la } \\
\text { Poudrière }\end{array}$ & Larch forest & 1992 & 7.42459 & 44.01388 & 30.6 .10 & 10 \\
\hline 2010 & M100630-SS01 & Saorge & $\begin{array}{l}\text { Tête de la } \\
\text { Poudrière }\end{array}$ & Larch forest & 1953 & 7.42407 & 44.01454 & 30.6 .10 & $\begin{array}{l}1 \text { (earth- } \\
\text { worms) }\end{array}$ \\
\hline 2010 & M100630-SS02 & Saorge & $\begin{array}{l}\text { Tête de la } \\
\text { Poudrière }\end{array}$ & Larch forest & 1992 & 7.42459 & 44.01388 & 30.6 .10 & $\begin{array}{l}1 \text { (earth- } \\
\text { worms) }\end{array}$ \\
\hline 2011 & $\begin{array}{l}\text { M110526-DB23 } \\
\text { to DB32 }\end{array}$ & Meyronnes & $\begin{array}{l}\text { Right bank of } \\
\text { Ubayette river }\end{array}$ & Larch and ash forest & 1491 & 6.796607 & 44.475409 & 26.5 .11 & 10 \\
\hline 2011 & $\begin{array}{l}\text { M110526-DB01 } \\
\text { to DB10 }\end{array}$ & Larche & $\begin{array}{l}\text { W of Col de } \\
\text { Larche: Forêt } \\
\text { de Boisset }\end{array}$ & Larch forest & 1986 & 6.878456 & 44.422731 & 26.5.11 & 10 \\
\hline
\end{tabular}

sequenced was identified, often photographed, assigned a collection code and placed in a well of a 96-well plate associated with a sheet summarizing its sampling data and taxonomic status. Our approach was to barcode several specimens (usually 6 to 8 ) of each population of a species, always keeping some specimens in alcohol for reference and potential further analysis. Preliminary identifications were conducted prior to barcoding for ants and Collembola; after barcoding, when necessary, specimens of these groups were mounted on slides for final identification (Porco et al. 2010). Other groups were 

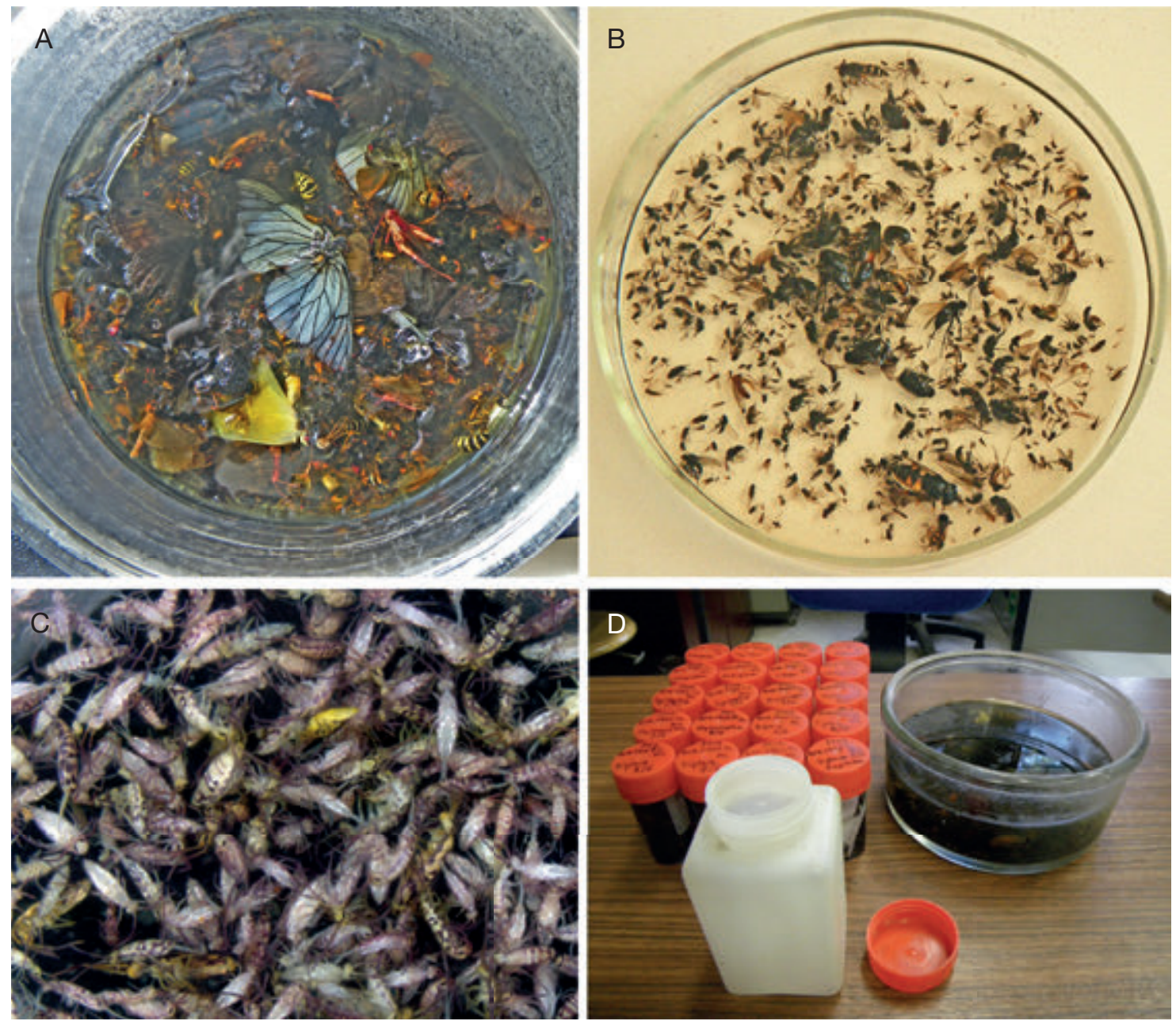

FIG. 7. - Sorting and storage: A, B, C, fauna obtained from a Malaise trap; A, the initial brute sample; B, subset of the arthropods placed in a Petri dish for sorting; C, a swarm of Entomobrya nivalis (Linnaeus, 1758) (Collembola) after sorting; D, vials containing sub-samples of insects from a Malaise trap, awaiting sorting. Photograph: Louis Deharveng.

directly identified prior to barcoding; for most insects and arachnids, only legs or other parts of the body were used to extract DNA. Initial specimen processing was done by the SSM and sequencing itself carried out at in the Genoscope (CEA, Evry, France), according to the workflow described in Puillandre et al. (2012).

\section{Databasing}

All data related to the TIM activities and results were managed in the project database, a non-public, flexible database developed under 4D (4D SA, France). The database is organized on the model of the PASCALIS database (Gibert et al. 2005), with supplementary fields and tables for storing taxon status from the first sorting phase to final identification, codes attached to specimens, barcoding results, INPN species lists and publications concerning TIM material.

According to the ATBI project agreement, data on selected records or specimens are regularly extracted from the project database and transmitted to three MNHN services for integration in their databases:
- INPN (CardObs database) for records of all identified species;

- SSM (MOLECULAIRE database) for barcoded specimen data; - Collections (ARTHROTER database, via JACIM) for identified or barcoded specimens deposited in the MNHN collections.

Specimens (ARTHROTER, MOLECULAIRE) or records (CardObs) are integrated in databases under system-specific registration numbers whose rationale is based on the scope of each database. Additional codes have often been provided by the collectors. As a result, up to five different codes may be attached to a single specimen: collector code, project code, collection code, molecular code and INPN code. The project code is stored in the three MNHN databases, and specimen/record codes of these three databases are, in part, stored in the project database. This database also contains information on all specimens collected and sorted by the TIM, while the other databases concern only a limited subset of these specimens. The project database therefore serves as a hub for the TIM data, connecting all the external codes through the project code. 


\section{RESULTS AND DISCUSSION}

The overall contribution of the Terrestrial Invertebrates Module to the inventory of the biodiversity of the MNP is summarized in Table 4. These results are extracted from the project database, which contains all information on samples (sorted or unsorted), and taxa (identified to any taxonomic level) obtained within the framework of the TIM. Sorting and identification of the collected material began in 2010 and is far from being completed. The total number of samples made during the three years of field trips (2009-2011) by the TIM is 1243 (618 from integrated sampling plus 625 from independent sampling). Of this number, 761 have been totally or partially sorted, i.e. only slightly more than half (Table 4). The results presented below have to be considered in this context.

\section{TAXA OBTAINED ACCORDING TO SAMPLING TECHNIQUE}

The numbers of taxa and specimens obtained by different techniques cannot be used to compare their efficiency directly because taxa were obtained over different lapses of time and are often identified to very different taxonomic levels. Nevertheless, when pooled together according to sampling method, these data do provide useful information about the relative contribution of each method employed to the overall biodiversity of the MNP (Table 5). The largest numbers of invertebrate specimens were obtained from Malaise traps, followed by pitfall traps and Berlese extraction. Ranked by the number of taxa per sample, the most productive technique was Malaise, followed by sifting and interception. The number of specimens collected in pitfall traps is highly variable, due to the highly localized distributions of groups like springtails and ants. For instance, as many as 30000 specimens of Hypogastrura sablbergi (a springtail) were obtained in a single pitfall trap at the $1400 \mathrm{~m}$ Boréon site. Conversely, the taxonomic richness and abundance obtained by Berlese extraction is strongly under-evaluated for our samples, largely because mites, the most diversified taxa in soils, have not been considered beyond ordinal or sub-ordinal rank in most cases.

\section{TAXA AND TAXONOMIC GAPS}

The diversity data gathered by the TIM for different taxa are summarized in Tables 6-7 and Figs 8-9. The number of recognized species and genera continues to grow significantly, following newly sorted material and new identifications. Given the large proportion of specimens awaiting identification at the species level (Tables 4,7) and the number of samples yet to be sorted ( $40 \%$ of the total, Table 4), this trend will last for years. However, progress will be slower than before, because an increasing part of the taxa remaining to be identified will belong to groups where expertise is lacking, and because funding of the project has come to its end.

At a finer resolution, the breakdown by orders (Table 7) clearly shows considerable taxonomic gaps and unevenness in our dataset, which can only partially be explained by scale effects (statistically, larger species tend to be collected in lower number than smaller ones) or aggregation effects. In
TABLE 4. - The contribution of the Terrestrial Invertebrates Module to the inventory of biodiversity in the MNP.

\begin{tabular}{lr}
\hline Total No. samples & 1243 \\
\hline No. samples totally or partially sorted & 761 \\
\hline Total No. records & 11289 \\
\hline No. records identified to family & 2488 \\
No. records identified to genus & 1155 \\
No. records identified to sp or ssp & 5887 \\
\hline Total No. specimens & $\mathbf{2 5 9} 412$ \\
\hline No. specimens identified to family & 47080 \\
No. specimens identified to genus & 11986 \\
No. specimens identified to sp or ssp & 67806 \\
\hline No. orders & $\mathbf{2 8 9}$ \\
\hline No. families & 211 \\
\hline No. families with specimen(s) sorted to genus & 1022 \\
\hline No. genera & 994 \\
\hline No. genera with specimen(s) sorted to species & 1844 \\
\hline No. sp + ssp + morphospecies + nsp & 1725 \\
\hline No. sp or ssp & 37 \\
No. new species & 82 \\
\hline No. morphospecies + nsp & \\
\hline
\end{tabular}

TABLE 5. - Numbers of samples and taxa produced by the different techniques.

\begin{tabular}{|c|c|c|c|c|c|c|}
\hline Technique & 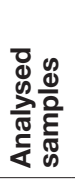 & 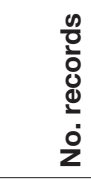 & 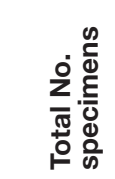 & 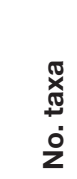 & 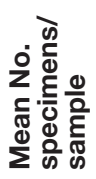 & 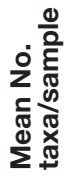 \\
\hline beating & 7 & 41 & 431 & 30 & 62 & 6 \\
\hline Berlese & 138 & 761 & 18418 & 220 & 133 & 6 \\
\hline hand collecting & 246 & 519 & 1263 & 252 & 5 & 2 \\
\hline digging/earthworms & 6 & 10 & 24 & 8 & 4 & 2 \\
\hline interception trap & 76 & 1440 & 13792 & 414 & 181 & 19 \\
\hline light trap & 19 & 314 & 757 & 183 & 40 & 17 \\
\hline Malaise trap & 121 & 7557 & 181415 & 1322 & 1499 & 62 \\
\hline pitfall trap & 40 & 137 & 40341 & 76 & 1009 & 3 \\
\hline sifting & 9 & 73 & 1669 & 62 & 185 & 8 \\
\hline snail collecting & 56 & 219 & 507 & 83 & 9 & 4 \\
\hline hand-netting & 35 & 189 & 390 & 121 & 11 & 5 \\
\hline flotation & 8 & 29 & 405 & 22 & 51 & 4 \\
\hline Total & 761 & 11289 & 259412 & 2176 & & \\
\hline
\end{tabular}

addition, several ordinal-level taxa, represented by a single occurrence in the sorted material, are not listed in Table 7, viz. Chilopoda Scolopendromorpha, Ostracoda (Crustacea), Callipodida (Diplopoda), Pauropoda, Basommatophora (Gastropoda, Pulmonata), Microcoryphia (Insecta), and Tubificida (Oligochaeta). These gaps are only partially filled by other sources of information (literature data and other datasets of the M-MA project). They are due in part to delays in sorting and identification of some groups, but mostly to insufficient availability of specialists for several groups (e.g. Braconidae among Hymenoptera, Phoridae among Diptera and Campodeidae among Diplura). At this stage, finding means to fill these gaps has become a major concern for the ATBI. 


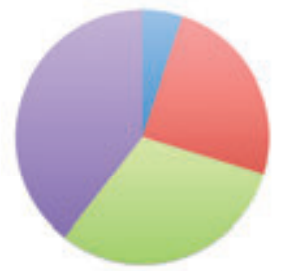

No. of analysed samples

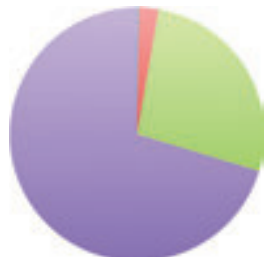

Total No. specimens No. of identified species

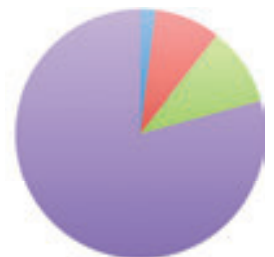

No. of records

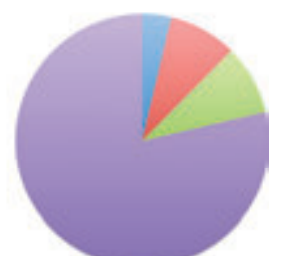

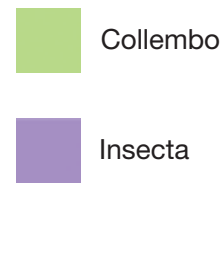

FIG. 8 - Relative contributions of the main groups to the diversity of terrestrial invertebrates of the Mercantour National Park.

\section{ENDEMISM AND GEOGRAPHICAL PATTERNS}

Endemism is particularly high in the flora and fauna of the southwestern Alps, and one of the ultimate goals of the project is to reconstitute patterns of endemism across different invertebrate taxa. At this stage, however, the data are too imprecise and uneven to allow such comparisons, especially for high altitude and subterranean species that are expected to constitute the bulk of endemic species within the region. The breakdown of diversity counts by valleys and altitudes is summarized in Table 8. Geographical unevenness is high, with a few sites being intensively sampled and many large areas being under-sampled. Despite these biases, the data obtained for the four valleys and the two altitudes suggest two patterns in the regional biodiversity of invertebrates.

Firstly, the total number of identified species in our dataset is lower at $2000 \mathrm{~m}$ than at $1400-1500 \mathrm{~m}$, except in Caïros valley where the opposite is the case (Fig. 9).

Conversely, the number of species new to science is higher at $2000 \mathrm{~m}$ than at 1400-1500 m at all sites, including Caïros. Whether this pattern reflects an increase in the proportion of endemics with elevation (as documented, for instance, by Trigas et al. 2013) or a lower taxonomic knowledge of the high altitude fauna in the region are open questions that will be examined in further investigations.

Secondly, the number of species new to science in our samples increases from north to south across the 4 studied valleys, with a peak at Caïros $2000 \mathrm{~m}$. Although the data are preliminary, this is at least consistent with a north to south gradient of increasing endemicity, as demonstrated for plants (Pawlowski 1970) and previously suggested for various invertebrate groups (Billi et al. 2011). In the southwestern Alps, Quaternary glacial impact is classically considered to explain much of this pattern, but this has been expressed in terms of hotspots rather than a gradient as such (Casazza et al. 2008). Three classes of invertebrates (Arachnida, Collembola and Insecta) have a species richness sufficient to allow meaningful comparisons across sites (Table 9). Their diversity can be
TABLE 6. - Breakdown of diversity counts by class. *, not identified at class level; "No. species" refers to total number of species, subspecies and morphospecies identified.

\begin{tabular}{|c|c|c|c|c|}
\hline Class & $\begin{array}{c}\text { Analyzed } \\
\text { samples }\end{array}$ & $\begin{array}{l}\text { No. } \\
\text { records }\end{array}$ & $\begin{array}{c}\text { Total No. } \\
\text { specimens }\end{array}$ & $\begin{array}{c}\text { No. } \\
\text { species }\end{array}$ \\
\hline Oligochaeta & 38 & 73 & 174 & 20 \\
\hline Gastropoda & 60 & 223 & 514 & 67 \\
\hline Arachnida & 288 & 950 & 6539 & 158 \\
\hline Myriapoda* & 8 & 8 & 117 & 0 \\
\hline Chilopoda & 7 & 8 & 12 & 0 \\
\hline Diplopoda & 31 & 38 & 82 & 10 \\
\hline Pauropoda & 1 & 1 & 2 & 0 \\
\hline $\begin{array}{l}\text { Crustacea } \\
\quad \text { Malacostracea }\end{array}$ & 8 & 10 & 73 & 1 \\
\hline $\begin{array}{l}\text { Crustacea } \\
\text { Ostracoda }\end{array}$ & 1 & 1 & 1 & 0 \\
\hline Collembola & 359 & 1132 & 69836 & 162 \\
\hline Protura & 9 & 9 & 140 & 0 \\
\hline Insecta & 462 & 8836 & 181922 & 1426 \\
\hline Total & & 11289 & 259412 & 1844 \\
\hline
\end{tabular}

ranked as (Insecta $>>>$ Arachnida $>$ Collembola) at all sites, except for CAI1400 where Collembola are more diversified than spiders. Because they represent 68 to $89 \%$ of identified species, insects exhibit the same altitudinal and latitudinal pattern as the pooled taxa of Table 8. Interestingly, the pattern for arachnids (mostly spiders) along the north-south gradient (decreasing from north to south) is similar to that of insects at $2000 \mathrm{~m}$, but the reverse is true at $1400-1500 \mathrm{~m}$ (increasing from north to south). Patterns of species richness in Collembola do not match those of insects or spiders at 1400-1500 m, and they show the opposite trend at $2000 \mathrm{~m}$ (increasing from north to south).

Evidence that species richness and endemicity respond to environmental variables is therefore strong for elevation. There are also indications of a link between endemicity and latitude, but the data gives conflicting results concerning relationships between species richness and latitude. The latter pattern will have to be re-evaluated when the dataset becomes more homogeneous for taxa and sites through more complete sorting and identification.

\section{BARCODING RESULTS}

In total, 2800 sequences have been obtained, comprising 2485 for the gene COI and 315 for $28 \mathrm{~S}$. These are registered in the database MOLECULAIRE of the MNHN (restricted access) and, in large part, deposited in the BOLD database (Table 10). The largest numbers of sequences were obtained for Gastropoda and Collembola. Work is under way to exploit these results from taxonomic and evolutionary perspectives, as summarized above in the objectives of the project, and identifications related to sequences will be released in connection with publications on the different groups.

\section{PUblications AND OTHER OUTPUTS}

The most significant output of the TIM activities in the Mercantour Park is the present special issue in Zoosystema. Several taxonomic papers have also been published elsewhere. They confirm the presence of two rare species of Raphidioptera in 
TABLE 7. - Breakdown of diversity counts by orders and suborders. *, not identified at ordinal level; "No. species", refers to total number of species, subspecies and morphospecies. Orders and suborders are ranked in alphabetical order within each class.

\begin{tabular}{|c|c|c|c|c|c|}
\hline Class & Order/suborder & $\begin{array}{l}\text { Analyzed } \\
\text { samples }\end{array}$ & No. records & No. specimens & No. species \\
\hline Oligochaeta & Opisthopora & 37 & 72 & 171 & 20 \\
\hline Gastropoda & Gastropoda* & 4 & 4 & 7 & 0 \\
\hline Gastropoda & Neotaenioglossa & 6 & 6 & 100 & 1 \\
\hline Gastropoda & Pulmonata Acteophila & 2 & 2 & 8 & 1 \\
\hline Gastropoda & Pulmonata Architaenioglossa & 9 & 11 & 6 & 4 \\
\hline Gastropoda & Pulmonata Stylommatophora & 54 & 199 & 392 & 60 \\
\hline Arachnida & Acari & 12 & 13 & 2180 & 0 \\
\hline Arachnida & Arachnida* & 100 & 100 & 1645 & 0 \\
\hline Arachnida & Araneae & 165 & 563 & 1170 & 124 \\
\hline Arachnida & Opiliones & 146 & 189 & 1306 & 15 \\
\hline Arachnida & Pseudoscorpiones & 63 & 85 & 238 & 19 \\
\hline Myriapoda & Myriapoda* & 8 & 8 & 117 & 0 \\
\hline Chilopoda & Geophilomorpha & 2 & 2 & 2 & 0 \\
\hline Chilopoda & Lithobiomorpha & 5 & 5 & 9 & 0 \\
\hline Diplopoda & Chordeumatida & 2 & 2 & 2 & 1 \\
\hline Diplopoda & Glomerida & 12 & 13 & 19 & 2 \\
\hline Diplopoda & Julida & 12 & 13 & 36 & 3 \\
\hline Diplopoda & Polydesmida & 2 & 2 & 2 & 1 \\
\hline Diplopoda & Polyxenida & 7 & 7 & 22 & 2 \\
\hline $\begin{array}{r}\text { Malacostraca } \\
\text { (Crustacea) }\end{array}$ & Oniscida (Isopoda) & 8 & 10 & 73 & 1 \\
\hline Collembola & Collembola* & 102 & 102 & 6923 & 0 \\
\hline Collembola & Entomobryomorpha & 230 & 562 & 15730 & 82 \\
\hline Collembola & Neelipleona & 18 & 19 & 147 & 4 \\
\hline Collembola & Poduromorpha & 145 & 369 & 46629 & 62 \\
\hline Collembola & Symphypleona & 65 & 80 & 407 & 14 \\
\hline Protura & Protura* $^{*}$ & 9 & 9 & 140 & 0 \\
\hline Insecta & Blattodea & 6 & 6 & 12 & 0 \\
\hline Insecta & Coleoptera & 222 & 1887 & 10540 & 305 \\
\hline Insecta & Dermaptera & 13 & 16 & 54 & 4 \\
\hline Insecta & Diptera & 219 & 2743 & 99626 & 239 \\
\hline Insecta & Hemiptera & 201 & 855 & 9529 & 168 \\
\hline Insecta & Hymenoptera & 362 & 2136 & 42006 & 394 \\
\hline Insecta & Insecta* & 180 & 180 & 10243 & 0 \\
\hline Insecta & Lepidoptera & 217 & 648 & 8415 & 276 \\
\hline Insecta & Mecoptera & 29 & 35 & 64 & 2 \\
\hline Insecta & Neuroptera & 85 & 136 & 206 & 30 \\
\hline Insecta & Orthoptera & 13 & 13 & 55 & 0 \\
\hline Insecta & Plecoptera & 63 & 63 & 718 & 0 \\
\hline Insecta & Psocoptera & 26 & 26 & 87 & 0 \\
\hline Insecta & Raphidioptera & 24 & 29 & 50 & 6 \\
\hline Insecta & Strepsiptera & 6 & 6 & 18 & 0 \\
\hline Insecta & Thysanoptera & 15 & 15 & 72 & 0 \\
\hline Insecta & Trichoptera & 40 & 41 & 226 & 2 \\
\hline
\end{tabular}

the MNP (Tillier 2013a), and report two species of Neuroptera new for the Alps (Tillier 2012a). Seven species of insects represent new records for France: one Lepidoptera (Leraut 2012), three Heteroptera (Matocq \& Streito 2013) and three Neuroptera (Tillier 2012b, 2013b). As part of these studies, updated lists have been published for the French species of Hemerobiidae (Tillier 2012a) and Coniopterygidae (Tillier 2013b). An article by Lefebvre et al. (2014) in Biology Letters shows that Diptera and notably Empididae become the main flower visitors at higher altitudes, instead of bees. Finally, a book entitled "Biodiversité des Alpes, L'inventaire sans frontières" by Francine Brondex et Lise Barnéoud (in press), provides a popular account on various aspects of the ATBI, including the activities of the TIM.

Collections and data provided by the TIM have also allowed the production of academic theses on the biodiversity of Ichneumonidae (Muru 2009) and Empididae (Lefebvre 2012) in
MNP, the distribution of the biodiversity of four hexapod taxa (Names 2013) and the creation of a modern reference collection combining molecular data and taxonomic identifications (Brisset 2012). In addition, a thesis is in progress since 2013 on the diversity and pollination activity of Empidinae in the MNP by V. Lefebvre. One communication on this subject (Lefebvre \& Daugeron 2013) and an account on the organization of field work of the TIM (Deharveng \& Isaia 2013) were presented during the "Journées transfrontalières d'échanges scientifiques et techniques de l'Inventaire Biologique Généralisé (IBG) Mercantour/Alpi Marittime", where a workshop entitled "Prospections" was organized by members of the TIM. Finally, Thomas (2012) presented the ATBI+M project on the website of the Ministry of Foreign and European Affairs (posted on the websites of several French Embassies around the world). The ATBI, including the TIM activities, has also frequently been the subject of coverage by local and national media. 

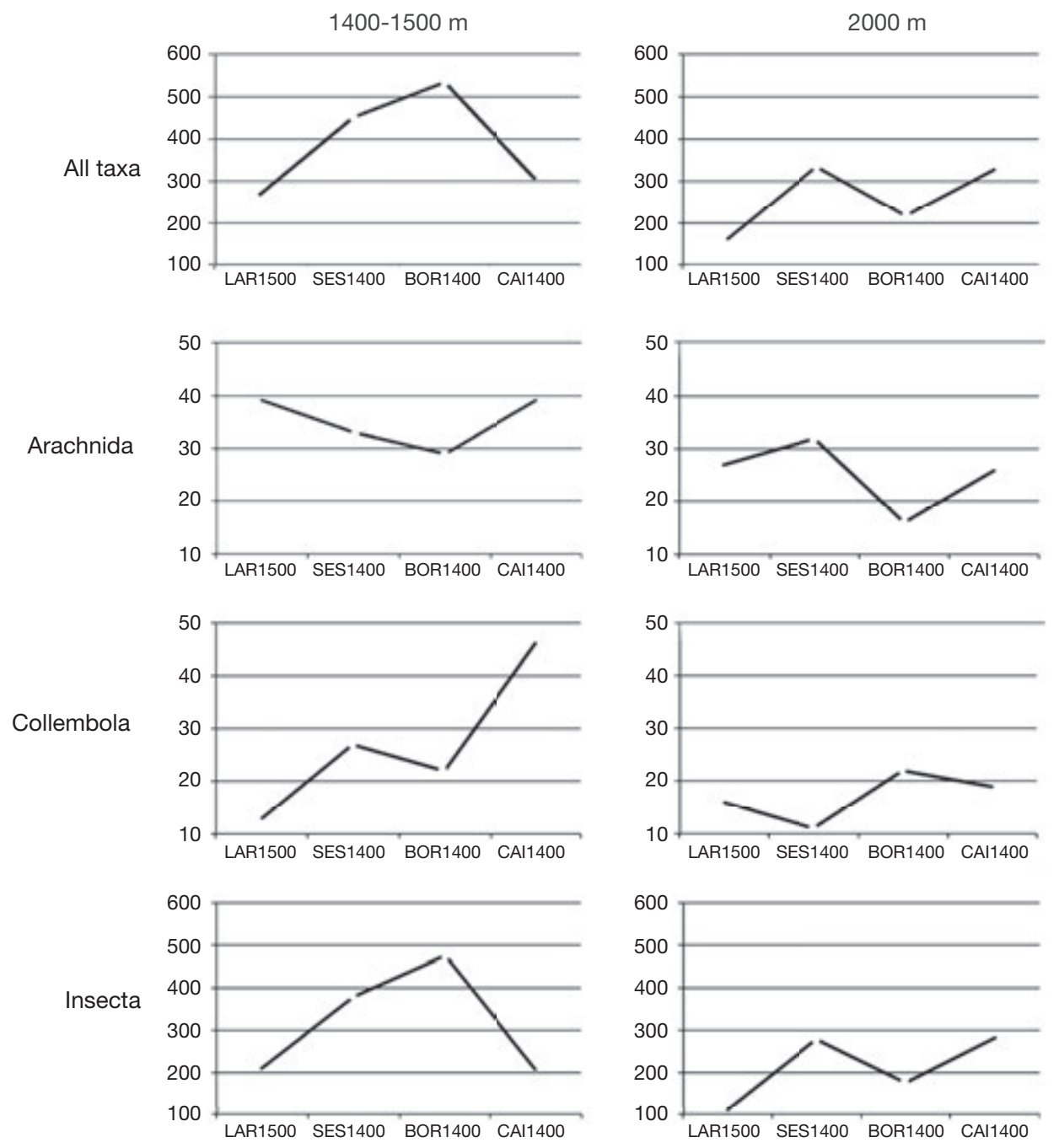

FIG. 9. - Diversity patterns by altitudes and sites. Ordinates, number of species, subspecies and morphospecies; Abscissae, site names ordered from north (LAR) to south (CAI).

\section{PERSPECTIVES}

A complete list of all the species collected so far in the Mercantour/Alpi Marittime parks is available on the INPN website (http://inpn.mnhn.fr/espece/inventaire/I221?lg=en). More detailed information about species records up to the end of 2010 is available on the EDIT website (http://www. atbi.eu/mercantour-marittime/?q=node/481) and through the GBIF (http://www.gbif.org/dataset/95d672e8-f76211e1-a439-00145eb45e9a). Data after this date are not accessible to the public, but the Mercantour National Park can make them available to qualified scientists in the context of studies or inventories of wider areas, provided that the request is accompanied by an explanation of the project and that a data exchange agreement is signed. Because no baseline species list was available at the start of the project, statistics on the contribution of the TIM to our knowledge of the biodiversity of the Mercantour park, in terms of taxa added or extension of geographical ranges, can only be produced for a few groups (see below). Such statistics for all taxa would be extremely useful for detecting geographical and taxonomical gaps, and hence for planning more efficient sampling in future.

Filling taxonomic gaps is the most immediate challenge for rapidly increasing our knowledge of the terrestrial invertebrate fauna of the Mercantour National Park. Future work will focus on groups and sites that have been the most undersampled so far.

A compilation of many taxonomic papers and local inventories of invertebrates available before the ATBI+M project gave an overview of the diversity of several speciose groups in the park, including snails, the 359 species of beetles listed in Valladares et al. (2013) and the 42 species of Orthoptera listed by Lemonnier (1999). The ATBI gave the opportunity to collect invertebrates at a much larger scale than attempted before. In this context, the TIM added hundreds of species to the PNM inventory within the groups Araneae, Opiliones, Pseudoscorpiones, Collembola, Diptera, Hemiptera, Coleoptera, Hymenoptera and Lepidoptera. Other speciose supra-generic taxa remain 
TABLE 8. - Biodiversity statistics of the reference sites.

\begin{tabular}{|c|c|c|c|c|c|c|}
\hline $\begin{array}{l}\text { Reference } \\
\text { site }\end{array}$ & 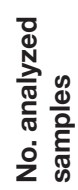 & $\begin{array}{l}\frac{n}{0} \\
0 \\
0 \\
0 \\
0 \\
2\end{array}$ & ○ं & 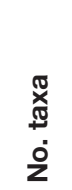 & 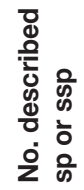 & 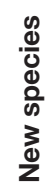 \\
\hline LAR1500 & 76 & 1349 & 28602 & 410 & 268 & 1 \\
\hline LAR2000 & 81 & 1007 & 25730 & 281 & 161 & 2 \\
\hline SES1400 & 60 & 1430 & 21024 & 630 & 450 & 2 \\
\hline SES2000 & 51 & 923 & 20491 & 452 & 332 & 3 \\
\hline BOR1400 & 46 & 1878 & 75749 & 722 & 534 & 1 \\
\hline BOR2000 & 55 & 959 & 19503 & 337 & 217 & 4 \\
\hline CAl1400 & 73 & 1417 & 24389 & 464 & 305 & 6 \\
\hline CAI2000 & 52 & 1363 & 39490 & 466 & 326 & 8 \\
\hline
\end{tabular}

TABLE 9. - Number of described species or subspecies per reference site for the main classes of invertebrates.

\begin{tabular}{|c|c|c|c|c|c|c|}
\hline $\begin{array}{l}\text { Reference } \\
\text { site }\end{array}$ & 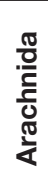 & $\begin{array}{l}\frac{\pi}{0} \\
\frac{0}{E} \\
\frac{E}{0} \\
0\end{array}$ & $\begin{array}{l}\text { 중 } \\
\frac{0}{0} \\
\text { 응 } \\
\text { 음 }\end{array}$ & 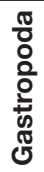 & 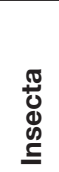 & 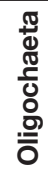 \\
\hline LAR1500 & 39 & 13 & 0 & 7 & 209 & 0 \\
\hline LAR2000 & 27 & 16 & 1 & 7 & 110 & 0 \\
\hline SES1400 & 33 & 27 & 4 & 3 & 378 & 5 \\
\hline SES2000 & 32 & 11 & 1 & 0 & 279 & 9 \\
\hline BOR1400 & 29 & 22 & 2 & 0 & 476 & 5 \\
\hline BOR2000 & 16 & 22 & 3 & 0 & 173 & 3 \\
\hline CAI1400 & 39 & 46 & 2 & 0 & 207 & 11 \\
\hline CAI2000 & 26 & 19 & 0 & 0 & 280 & 1 \\
\hline
\end{tabular}

TABLE 10. - Barcoding results deposited in the international data repository BOLD (Barcode Of Life Database). n.c., not calculated; BINs, Barcode Index Numbers (Ratnasingham \& Hebert 2013).

\begin{tabular}{|c|c|c|c|c|c|c|c|}
\hline Taxon & 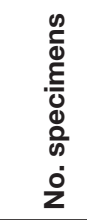 & 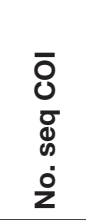 & 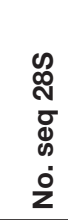 & 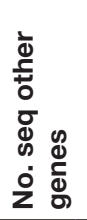 & $\begin{array}{l}0 \\
\frac{0}{0} \\
\Phi \\
0 \\
0 \\
\vdots \\
Z\end{array}$ & 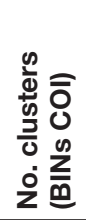 & 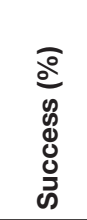 \\
\hline Araneae & 192 & 155 & 0 & 0 & 28 & 31 & 80.73 \\
\hline Opiliones & 96 & 0 & 0 & 0 & 16 & 0 & 0.00 \\
\hline Coleoptera & 96 & 73 & 0 & 0 & 27 & 24 & 76.04 \\
\hline Collembola & 1444 & 896 & 185 & 0 & 78 & 169 & 62.05 \\
\hline Hymenoptera & 710 & 621 & 0 & 0 & 142 & 168 & 87.46 \\
\hline Lumbricidae & 96 & 31 & 0 & 0 & 15 & 10 & 32.29 \\
\hline Gastropoda & 902 & 611 & 46 & 63 & 101 & n.c. & 67.74 \\
\hline Total & 3536 & 2387 & 231 & 63 & 407 & & 67.51 \\
\hline
\end{tabular}

under-sampled or unsorted, such as nematodes, mites (only two species listed in CardObs in 2009, and very few additional ones since then), terrestrial isopods, millipedes, several large families of Hymenoptera (e.g., Braconidae) and Diptera (e.g. Phoridae), a few families of Coleoptera (e.g. Pselaphidae), scale insects and various smaller taxa. A lot of identification work therefore remains to be carried out and is likely to add hundreds of species to the M-AM inventory. The contribution of the TIM to the ATBI is currently under estimation in terms of species new for the PNM, from analysis of the current ATBI databases.

Of particular concern at this stage is the spatial distribution of samples in the large territory covered by the M-AM project, since most of the currently available data are concentrated at a few spots, even considering records obtained outside the module's activities. The richest of these spots represent the reference sites operated during our fieldwork. Between them are large undersampled areas, sometimes encompassing very diverse habitats. Regarding terrestrial invertebrates, the Alpine belt and wetlands have been neglected in comparison with forests and forest edges. Several microhabitats potentially rich in endemic species, such as deep soil, rotten wood or moss on rocks, have been under-sampled relative to forest litter. Overall, the results can be used for rough macroecological analyses, but the geographic and ecological gaps are too wide for reconstructing robust patterns of biodiversity across the whole MNP area in relation to environmental features like vegetation types.

In the light of this four-year experience, the ambitious objective of a "complete" biological inventory now appears to be unattainable even in the mid-term, at least for invertebrates, in such a large and ecologically diverse area. A return to the initial proposal of EDIT, focusing on a set of much smaller areas and redirecting efforts towards "less known taxa in less known sites", would allow better integration of different approaches, produce faster outcomes and be more rewarding for participants and organizers. Selecting such sites is now relatively easy, given the large amount of spatial data accumulated. It would also facilitate the combination of pure inventory and wider ecological approaches, which are both necessary and complementary for the understanding and management of biodiversity in the Mercantour.

\section{Acknowledgements}

We are deeply indebted to all the taxonomist experts, whose contributions made the project work. We thank the staff of the Mercantour National Park, who contributed actively to the project, in particular Marie-France Leccia, Jérôme Molto, Elise Minssieux, Patrice Tordjman and Antony Turpaud. Thomas Théry and Magdalena Czyrnek had the heavy tasks of sorting and sending specimens for identification or barcoding, which they carried out perfectly. Julien Brisset efficiently managed specimen barcoding process and various tasks at the interface with collections. Olivier Gargominy kindly helped with mapping, provided essential data about Mercantour biodiversity and patiently managed data importation into CardObs. The project was funded by the European project EDIT, the Mercantour National Park and the MNHN, the latter including contributions by the Direction des Collections, the Service de Systématique Moléculaire, the Service du Patrimoine Naturel and the Département Systématique et Évolution. 


\section{REFERENCES}

Achterberg C. van, Grootaert P. \& Shaw M. R. 2010. — Chapter 17. Flight interception traps for arthropods, in EYMANN J., Degreef J., Häuser C., Monje J.C., Samyn Y. \& VandenSPIEGEL D. (eds), Manual on field recording techniques and protocols for all taxa biodiversity inventories and monitoring. Abc Taxa 8 (2): 423-462.

Bedos A., Prié V. \& Deharveng L. 2011. - Focus on soils, in Bouchet P., Le Guyader H. \& Pascal O. (eds), The Natural History of Santo. Muséum national d'Histoire naturelle, Paris; IRD, Marseille; PNI, Paris. Patrimoines naturels 70: 288-295.

Bernard E. C. \& Felderhoff K. L. 2007. — Biodiversity Explosion: Collembola (springtails) in Great Smoky Mountains National Park. Southeastern Naturalist special issue (1): 175-182.

Billi F., Bourgon A., Cornet M., Desriaux P., George G., Iorio E., RyMarczyK F. \& VARENne T. 2011. - Insectes, arachnides et myriapodes des Alpes-Maritimes: une faune riche, originale et vulnérable. Riviéra scientifique 100: 101-120.

Bouchet P., Le Guyader H. \& Pascal O. 2008. — Des voyages de Cook à l'expédition Santo 2006: un renouveau des explorations naturalistes des îles du Pacifique. Journal de la Société des Océanistes 126-127: 167-185.

BRISSET J. 2012. - Constitution d'une collection moderne de référence dans le cadre de l'ATBI+M Mercantour/Alpi Marittime: du terrain aux données moléculaires en passant par les identifications taxonomiques. Mémoire Master 2, Muséum national d'Histoire naturelle, Paris.

BRONDEX F. \& BARnéoud L. (in press). - Biodiversité des Alpes, l'inventaire sans frontières. Editions Glénat.

Casazza G., Zappa E., Mariotti M. G., Médail F. \& Minuto L. 2008. - Ecological and historical factors affecting distribution pattern and richness of endemic plant species: the case of the Maritime and Ligurian Alps hotspot. Diversity and Distributions 14: 47-58.

Chapman A. D. 2009. - Numbers of Living Species in Australia and the World. Australian Biodiversity Information Services, Toowoomba, Canberra, $80 \mathrm{p}$.

Deharveng L. \& Isaia M. 2013. - Restitution de l'Atelier 1 "Prospections", in Actes des Journées transfrontalières d'échanges scientifiques et techniques - Inventaire Biologique Généralisé Mercantour/Alpi Marittime. Les Cahiers de Séolane 2: 21-28.

Deharveng L. \& SÉmah A. M. 2011. - The karst team, in Bouchet P., Le Guyader H. \& Pascal O. (eds), The Natural History of Santo: Caves and Soils. Muséum national d'Histoire naturelle, Paris; IRD, Marseille; PNI, Paris. Patrimoines naturels 70:267, 268.

Deharveng L., Dalens H., Drugmand D., Simon-Benito J. C., Da Gama M. M., Sousa P., Gers C. \& Bedos A. 2000. Endemism mapping and biodiversity conservation in western Europe: an Arthropod perspective. Belgian Journal of Entomology 2 (1): 59-75.

GaRRIgUe J. 2014. - La Massane, tour d'horizon 2014. Réserve Naturelle Nationale de la Massane, Banyuls-sur-Mer, 16 p.

Gibert J., Brancelj A., Camacho A., Castellarini F., De Broyer C., Deharveng L., Dole-Olivier M.J., Douady C., Galassi D., Malard F., Martin P., Michel G., Sket B., Stoch F., Trontelj P. \& VAldecasas A. 2005. - Groundwater Biodiversity. Protocols for the ASsessment and Conservation of Aquatic Life In the Subsurface (PASCALIS): overview and main results, in GiBERT J. (ed.), World Subterranean Biodiversity. Proceedings of an International Symposium held on 8-10 december 2004 in Villeurbanne, France: 39-52.

HäUSER C. L \& RIEDE K. 2015. — Field methods for inventorying insects. In Watson M. F., Lyal C. \& Pendry C. (eds), Descriptive taxonomy: the foundation of biodiversity research. Systematics Association Special Volume 84. Cambridge University Press, Cambridge: 190-213.
JANZEN D. H. \& HALlWACHS W. 1994. — All Taxa Biodiversity Inventory (ATBI) of Terrestrial Systems. A generic protocol for preparing wildland biodiversity for non-damaging use. Report of a NSF Workshop, 16-18 April 1993, Philadelphia, Pennsylvania, 132 p.

LEFEBVRE V. 2012. - Diversité et action pollinisatrice des Empidinae (Diptera) dans le Parc national du Mercantour. Mémoire Master 2, Muséum national d'Histoire naturelle, Paris.

Lefebvre V., Fontaine C., Villemant C. \& Daugeron C. 2014. Are empidine dance flies major flower-visitors in alpine environments? A case study in the Alps, France. Biology Letters, published online November 5, 2014. http://dx.doi.org/10.1098/ rsbl.2014.0742

LEMONNIER M. 1999. - Les peuplements d'Orthoptères (Insecta : Orthoptera) du Parc National du Mercantour (Alpes-Maritimes, Alpes-de-Haute-Provence). Bulletin de la Société entomologique de France 104 (2): 149-166.

LERAUT P. 2012. — Le genre Nematopogon Zeller, 1839, en France, avec une espèce nouvelle pour ce pays (Lepidoptera, Adelidae). Bulletin de la Société Entomologique de France 117 (3): 375-379.

MatocQ A. \& STReito J. C. 2013. - Données sur trois espèces d'Hétéroptères nouvelles pour la France (Hemiptera Miridae et Anthocoridae). L'Entomologiste 69 (1): 3-7.

Mauz I. \& Granjou C. 2013. — L’ATBI, in Actes des Journées transfrontalières d'échanges scientifiques et techniques - Inventaire Biologique Généralisé Mercantour/Alpi Marittime. Les Cahiers de Séolane 2: 8-19.

MAUZ I. 2011. - Le renouveau des inventaires naturalistes au début du XXIe siècle. Quaderni 76: 13-23.

MÉDAIL F. \& DiADEMA K. 2009. - Glacial refugia influence plant diversity patterns in the Mediterranean Basin. Journal of Biogeography 36: 1333-1345.

MeDAIL F. \& Quezel P. 1997. - Hotspots analysis for conservation of plant biodiversity in the Mediterranean Basin. Annals of the Missouri Botanical Garden 84: 112-127.

Muru D. 2009. - Contribution à la connaissance de la biodiversité des Ichneumonidae (Insecta Hymenoptera) dans le Parc national du Mercantour. Mémoire Master 1, Muséum national d'Histoire naturelle, Paris.

NAMES G. 2013. - Macroecological Insights from the All Taxa Biodiversity Inventory in Mercantour National Park: The Distribution of the Biodiversity of Four Hexapod Taxa. Mémoire Master 1, ENS Paris.

Nichols B. J. \& Langdon K. R. 2007. - The Smokies All Taxa Biodiversity Inventory: history and progress. Southeastern Naturalist 6 (1): $27-34$

PAWLOWSKI B. 1970. - Remarques sur l'endémisme dans la flore des Alpes et des Carpates. Vegetatio 21 (4/6): 181-243.

Porco D., Rougerie R., Deharveng L. \& Hebert P. 2010. Coupling non-destructive DNA extraction and voucher retrieval for small soft-bodied arthropods in a high-throughput context: the example of Collembola. Molecular Ecology Resources 10 (6): 942-945.

Puillandre N., Bouchet P., Boisselier-Dubayle M. C., Brisset J., Buge B., Castelin M., Chagnoux S., Christophe T., Corbari L., LAMBOURdière J., LOZOUET P., MARANi G., RivaSSeau A., Silva N., Terryn Y., Tillier S., Utge J. \& Samadi S. 2012. - New taxonomy and old collections: integrating DNA barcoding into the collection curation process. Molecular Ecology Resources 12 (3): 396-402.

RATNASINGHAM S. \& HEBERT P. D. N. 2013.—A DNA-Based Registry for All Animal Species: The Barcode Index Number (BIN) System. PLoS ONE 8 (8): e66213. http://dx.doi.org/10.1371/ journal.pone.0066213

Sainte-Claire Deville J. 1928. - Esquisse du peuplement des Alpes françaises (Coléoptères), in Allorge P., BenoistR., Chevalier A., Chopard L. , Germain L., Heim De Balsac H., Heim R., Humbert H., Jeannel R., Joleaud L., Lavauden L., Maire R., De Martonne E., Motas C., De Peyerimhoff P., Pittard E. , Sainte-Claire Deville J., Scharf R. F. (eds), 
Contribution à l'étude du peuplement des hautes montagnes. Mémoires de la Société de Biogéographie, 2, Paris: 86-106.

Sharkey M. J. 2001. - The All Taxa Biological Inventory of the Great Smoky Mountains National Park. The Florida Entomologist 84 (4): 556-564.

ThOMAS S. 2012. - Un gigantesque inventaire des espèces dans le parc du Mercantour. Ministère des Affaires etrangères et européennes, Actualités en France ${ }^{\circ} 22$. Various French Embassies websites like http://www.ambafrance-bo.org/Un-gigantesqueinventaire-des?lang=fr (Bolivia), http://www.ambafrance-cn. org/Un-gigantesque-inventaire-des-especes-dans-le-parc-duMercantour (China), http://www.ambafrance-gr.org/Un-gigantesque-inventaire-des (Greece), http://www.ambafrance-es.org/ Un-gigantesque-inventaire-des (Spain).

Tillier P. 2012a. - Drepanepteryx algida (Erichson in Middendorff, 1851) dans le Mercantour, espèce nouvelle pour la faune de France et liste actualisée des Hemerobiidae de France (Neuroptera). Bulletin de la Société entomologique de France 117 (4): 457-459.

Tillier P. 2012b. - Présence de Hemerobius (Hemerobius) schedli (Hölzel, 1970) dans les Alpes françaises (Neuroptera Hemerobiidae). L'Entomologiste 68 (4): 253-254.
Tillier P. 2013a. - Nouvelles captures de Raphidia (Raphidia) ligurica Albarda, 1891 et de Phaeostigma (Phaeostigma) italogallica (H. Aspöck \& U. Aspöck, 1976) dans le Mercantour (Raphidioptera Raphidiidae). L'Entomologiste 69 (2): 121-123.

Tillier P. 2013b. - Deux espèces du genre Helicoconis Enderlein, 1905 nouvelles pour la France et liste actualisée des Coniopterygidae de France (Neuroptera, Coniopterygidae). Bulletin de la Société entomologique de France 118 (2): 141-144.

Trigas P., PANITSA M. \& TSIFTSIS S. 2013. - Elevational Gradient of Vascular Plant Species Richness and Endemism in Crete - The Effect of Post-Isolation Mountain Uplift on a Continental Island System. PLoS ONE 8 (3): e59425. http://dx.doi.org/10.1371/ journal.pone.0059425

VAlladares L., Brustel H. \& BRIN A. 2013. - Contribution à la connaissance et à la conservation des coléoptères (Coleoptera) forestiers du parc national du Mercantour (France). Biocosme Mésogéen 30 (2): 35-59.

VASARHELYI T. 2007. - Three decades of zoological survey in national parks in Hungary (1974-2002). Acta Zoologica Academiae Scientiarum Hungaricae 5 (4): 397-410.

Submitted on 12 January; accepted on 26 February; published on 27 March 2015. 